\title{
UTILIZATION OF DATE PALM LEAVES TREATED WITH ENZYMES IN SMALL RUMINANTS FEEDING
}

\author{
Hend A. Aziz \\ Animal Nutrition Department, Desert Research Center, Cairo, Egypt.
}

(Received 30/12/2019, accepted 2/2/2020)

\section{SUMMARY}

\begin{abstract}
A im of the current study was to investigate the effects of feeding small ruminants on diets contained date palm tree leaves (DPL) incubated or not with enzymes. Biological treatments were used in laboratory experiment to determine the effect of using different enzymes (Cellulase, Taninnase, Fibrolytic and combinations of each with other) on chemical composition of date palm leaves. In vitro trail was conducted using diets contained $40 \%$ DPL incubated with enzymes to study in vitro nutrients disappearance. A digestibility trails were carried out to study digestibility coefficients, nutritive values, nitrogen balance, rumen fermentations and microbes and some blood components as follow: D (1): $50 \%$ concentrate feed mixture $(\mathrm{CFM})+50 \%$ berseem hay $(\mathrm{BH})$ (control diet). $\mathrm{D}(2): 50 \% \mathrm{CFM}+40 \% \mathrm{DPL}$ $+10 \%$ BH.D (3): $50 \%$ CFM +40\% DPL incubated with Cellulase enzyme $+10 \%$ BH. D (4): $50 \%$ CFM $+40 \%$ DPL incubated with Fibrolytic enzyme $+10 \%$ BH. D (5): $50 \%$ CFM +40\% DPL incubated with Cellulase and fibrolytic enzymes. Results showed that enzymes improved chemical composition of DPL, CP content was increased while $\mathrm{CF}$ and its fractions were decreased $(\mathrm{P} \leq 0.01)$. The incubation of DPL in diets with enzymes improved nutrients disappearance. Digestibility coefficients, nutritive values and nitrogen balance showed significant increase $(\mathrm{P} \leq 0.01)$ with diets contained enzymatic DPL. The highest improvement of rumen fermentations and microbes were reported with DPL contained enzymes compared to control and non- enzymatic DPL. Serum total proteins and albumin concentrations were increased significantly $(\mathrm{P} \leq 0.01)$, while urea concentration was decreased with diets contained enzymatic DPL.
\end{abstract}

Keywords: Date palm leaves, digestibility, rumen fermentations, microbes and sheep.

\section{INTRODUCTION}

In Egypt there is an acute shortage of conventional feedstuff for feedings livestock. The big feed gap between the requirements and the available sources forced the planners and nutritionists to look for nonconventional resources where there is no competition with human such as agricultural, agro-industrial and organic wastes. Encouraging results obtained from using by-products in animal diets could help in reducing the shortage of animal feeds. However, the nutritive value of the agricultural by-products like date palm leaves can be enhanced through their biological treatment and this way can play an important role to meet nutrient requirements of the animals.

Dates palm tree (Phoenix dactylifera) are very popular foods in most of the Middle Estern countries. Over $70 \%$ of the total world production is produced in this area. Egypt is the second important country in date world production which produced 1166182 tons annually (FAO, 2006). A date palm tree annually produced approximately $20 \mathrm{Kg}$ of leaves, which mean producing approximately 220000 tons of dry matter in Egypt annually.

Several attempts were devoted to improve feed utilization and eliminate the indigestible feeds in the animal waste including use of enzymes. Recently, the efficacy of many commercial enzyme products has been well stated, but there is still some vagueness in their mode of action (Bedford, 2002). It is well known that exogenous enzymes have been used to improve the feeding values of feedstuffs are high in soluble non- starch polysaccharides that induce viscosity (Lazaro et al., 2003). Enzymes bind temporally to one or more of the reactants which they catalyze and so lower the amount of energy needed thereby, speeding up the reaction (Ibrahim et al., 2010). Also, enzymes release other nutrients like minerals (Ibrahim et al., 2010), decreasing the ant-nutritional substances and improving animal performance (Goli and Aghdam Shahryar, 2015).

The current study aimed to investigate the effects of feeding small ruminants on diets contained date palm tree leaves incubated or not with enzymes. 


\section{MATERIALS AND METHODS}

\section{Laboratory trail:}

A laboratory trail was made in Desert Research Center laboratories to study the effect of using biological treatments (enzymes) on chemical composition and cell wall constituents of date palm leaves as follow:

$\mathrm{T}$ (1): Untreated date palm leaves (DPL).

$\mathrm{T}$ (2): DPL incubated with Cellulase enzyme.

$\mathrm{T}$ (3): DPL incubated with Taninnase enzyme.

$T$ (4): DPL incubated with Fibrolytic enzyme.

$\mathrm{T}(5)$ : DPL incubated with Cellulase and Taninnase enzymes.

$\mathrm{T}(6)$ : DPL incubated with Cellulase and Fibrolytic enzymes.

$T$ (7): DPL incubated with Taninnase and Fibrolytic enzymes.

Air-dried chopped date palm leaves ( $400 \mathrm{~g}$ ) were moistened for $60 \%$ and inculcated with $6 \mathrm{ml}$ from each enzyme $(1.5 \mathrm{ml}$ media to $100 \mathrm{~g})$ and the half amount of each enzyme for the combination of enzymes, $10 \%$ of molasses solution from the dry matter was added as a source of energy, also $4 \%$ urea from the dry matter was added as a source of amino acids. The mixture was put in plastic bag and kept closed, the inculcation lasted for 10 days at $30 \pm 2{ }^{\circ} \mathrm{C}$, then bags were opened and oven dried at $70{ }^{\circ} \mathrm{C}$ for chemical analysis.

\section{In vitro trail:}

Diets contain DPL incubated with different enzymes were used in in vitro trail to study the effect of enzymes on the chemical composition and in vitro nutrients disappearance of diets as follow:

D (1): $50 \%$ concentrate feed mixture (CFM) $+40 \%$ DPL incubated with Cellulase enzyme $+10 \%$ berseem hay $(\mathrm{BH})$.

D (2): $50 \%$ CFM + $40 \%$ DPL incubated with Taninnase enzyme $+10 \%$ BH.

D (3): $50 \%$ CFM + 40\% DPL incubated with Fibrolytic enzyme +10\% BH.

D (4): $50 \%$ CFM +40\% DPL incubated with Cellulase and Taninnase enzymes $+10 \% \mathrm{BH}$.

D (5): $50 \%$ CFM +40\% DPL incubated with Cellulase and Fibrolytic enzymes $+10 \%$ BH.

D (6): $50 \%$ CFM + 40\% DPL incubated with Taninnase and Fibrolytic enzymes +10\% BH.

The samples (three replicates for each diet) were incubated for 24 hours with ruminal fluid (collected two hours post feeding from six male sheep fed concentrate feed mixture and good quality berseem hay), in vitro nutrients disappearance were estimated according to the method by Norris (1976).

\section{Digestibility trails:}

The diets incubated with enzymes which gave the best chemical composition and in vitro nutrients disappearance were used in digestibility trails as follow:

D (1): $50 \% \mathrm{CFM}+50 \% \mathrm{BH}$ (control diet).

$\mathrm{D}(2): 50 \% \mathrm{CFM}+40 \% \mathrm{DPL}+10 \% \mathrm{BH}$.

D (3): $50 \%$ CFM + 40\% DPL incubated with Cellulase enzyme +10\% BH.

D (4): $50 \%$ CFM + 40\% DPL incubated with Fibrolytic enzyme +10\% BH.

D (5): $50 \%$ CFM +40\% DPL incubated with Cellulase and fibrolytic enzymes.

Twenty adult Barki male sheep about two years old and body weight about $50 \mathrm{~kg}$ (four animals for each group) were fed on diets for 30 days as palatability and adaptation period then rams were placed in metabolic cages for 20 days, the first 15 days were considered as an adaptation and preliminary period, the last 5 days were as collection period. The daily amount of feed consumed, residuals, feces and urine were estimated for each animal during the collection period.

\section{Laboratory analysis:}

Feeds, feces and urine proximate analysis were determined according to A.O.A.C. (1995). Neutral detergent fiber (NDF), acid detergent fiber (ADF) and acid detergent leginin (ADL) were determined according to the procedures of Van Soest, (1994).

\section{Urine analysis and microbial nitrogen supply:}

Urine samples were analyzed to Allantion by using a colorimetric method (Young and Conway, 1942). Uric acid was measured colorimetrically by the method of Fujihara et al., (1987). Xanthine and Hypoxanthine were measured together as uric acid after treatment of urine samples with xanthine oxidase 
according to procedure of Chen and Gomaes (1995). Allantion, uric acid, xanthine and Hypoxanthine (mmol/day) were used to calculate microbial purines (PD) excretion (Y,mmol/day). The amount of microbial purines (PD) absorbed (X, mmol/day) corresponding to the PD excreted (Y, mmol/day) was calculated from the relationship derived by Chen and Gomaes (1995) as follow:

$$
\mathrm{Y}=0.84 \mathrm{X}+\left(0.15 \mathrm{~W}^{0.75} \mathrm{e}^{-0.2 .5 \mathrm{X}}\right)
$$

The supply of microbial nitrogen (MN) in grams/day based on PD was estimated as follow: MN (g/d) $=70 \mathrm{X}(0.83 \times 0.116 \times 1000)=0.727 \mathrm{X}$ with $\mathrm{X}$ and $\mathrm{Y}$ being, respectively, the absorption and excretion of $\mathrm{PD}$ in mmol/day. The following assumption was made by Chen and Gomaes (1995):

1 - Digestibility of microbial purine is assumed to be 0.83 . This is taken as the mean digestibility value for microbial nucleic acids based on observations reported in the literature.

2- The $\mathrm{N}$ content in purines is $70 \mathrm{mg} \mathrm{N} / \mathrm{mmol}$.

3- The ratio of $\mathrm{N}$ content in purines in mixed rumen microbes is taken as 11.6: 100.

\section{Parameters of rumen liquor:}

At the end of the digestibility trail samples of rumen liquor were collected pre-feeding and 4 hours post feeding, $\mathrm{pH}$ was immediately measured using a digital $\mathrm{pH}$ meter. Total volatile fatty acids were estimated according to Warner (1964). Total nitrogen, non-protein nitrogen and ammonia nitrogen concentrations was determined using the methods of A.O.A.C (1995), true protein nitrogen was calculated (TN-NPN). Ruminal microbial protein was estimated as described by Makkar et al. (1982).

Description by Dehority (1993) used to publish the identification of genera and species of ruminal ciliate protozoa, while it's counts were determined using the method described by Ogimoto and Imai (1981).

\section{Blood serum:}

At the end of the digestibility trail blood samples were collected via jugular vein from each dietary treatment just before morning feeding and 4 hours post-feeding. Blood samples were left to coagulate at room temperature, then centrifuged at 4000 turn for 15 minute to separate serum and kept it frozen at $20^{\circ} \mathrm{C}$ till analyses. The method of Armstrong and Carr (1964) was used to analyze total proteins, albumin was analyzed according to Doumas and Biggs (1971), globulin was calculated by subtracting. Patton and Crouch (1977) method was used to analyze urea concentration. Blood GOT and GPT was analyzed according to Wikison et al., (1972).

\section{Statistical analysis:}

Statistical analysis of data was done using Statistical analysis system of SAS (2009). The one-way analysis design was used to analyze the chemical composition, cell wall constituent's, nutrients disappearance, digestibility coefficients, nitrogen utilization, the model was: $\mathrm{Yij}=\mathrm{M}+\mathrm{Ti}+\mathrm{eij}$.

The two-way analysis design was used to statistical analysis for rumen fermentations, rumen microbes and blood parameters, the model was: $Y_{i j}=\mu+T_{i}+I_{j}+T_{i j}+e_{i j}$. Where: $Y_{i j}=$ experimental observation, $\mu=$ general mean.

$T_{i}=$ effect of treatment $(i=1: 5), I_{j}=$ effect of sampling time $(j=0,4)$.

$\mathrm{TI}_{\mathrm{ij}}=$ effect of interaction of treatment and sampling time. $\mathrm{e}_{\mathrm{ij}}=$ experimental error.

Duncan's multiple test used to carry out the separation among means (Duncan, 1955).

\section{RESULTS AND DISCUSSION}

\section{Laboratorial trail:}

Table (1) indicated that the used enzymes (Cellulase, Taninnase, Fibrolytic enzymes or combinations with each other) did not significantly $(\mathrm{P} \leq 0.01)$ affect $\mathrm{DM}$ and $\mathrm{EE}$ content of date palm leaves, although those enzymatic treatments significantly $(\mathrm{P} \leq 0.01)$ increased $\mathrm{OM}, \mathrm{CP}, \mathrm{NFE}, \mathrm{NFC}$ and cellulose contents more than untreated DPL. In the same time, CF, NDF, ADF, ADL and hemicellulose contents were significantly $(\mathrm{P} \leq 0.01)$ decreased by enzymatic treatments. Also, the data indicated that enzymatic treatments with cellulase, fibrolytic enzymes and combinations of each other (T2, T4 and T6) were more efficient in increasing CP content and decreasing CF content and it's fractions more than taninnase and its combinations (T3, T5 and T7). 
Table (1): Chemical composition and cell wall constituents $(\%)$ of date palm leaves non- incubated or incubated with enzymes during laboratorial trail.

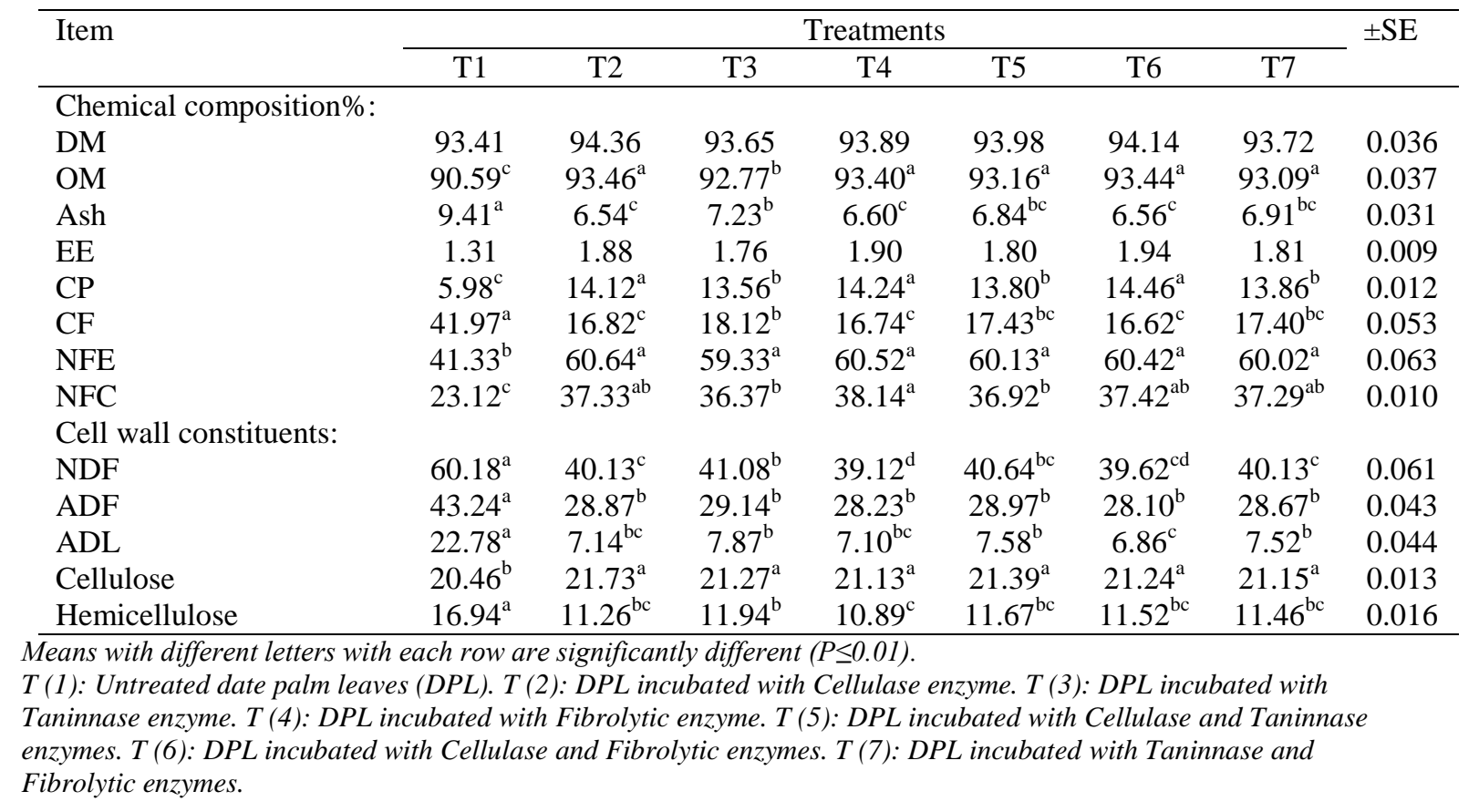

The increase in $\mathrm{CP}$ content by using enzymes may be due to enhance microbial colonization of feed (Morgavi et al., 2000 and Nsereko et al., 2000), and due to using 4\% urea as a source of NPN that is rapidly analyze to amino acids to form protein by microbial colonization (Shoukry, 1992 and Okab et al., 2012). While the decrease of CF content by progressed time of incubation may be due to cellulolytic bacteria which secreted cellulase enzymes to degrade crude fiber, or due to the utilization of CF by microbes for their growth (Aziz, 2014).

Similar results were found by Kholif et al., (2005) indicated that the fungal treatment led to increase CP and decreased CF and OM content. Also, Awawdeh and Obeidat (2013), Aziz (2014 and 2015) reported that the biological treatments showed a higher content of CP and a lower content of cell wall components comparing to other treatments.

\section{In vitro trail:}

Chemical composition of diets contained DPL after incubated with different enzymes that used in the in vitro trail is represented in Table (2). Diets contained 40\% DPL after incubated with cellulase, fibrolytic enzymes and combinations with each other (D1, D3 and D5) had slight higher values of DM, $\mathrm{OM}, \mathrm{EE}, \mathrm{CP}$ and cellulose more than other diets with no significant difference among them, although those diets had lower contents of CF and it's fractions more than other diets with no or slight significant difference among them. The present results are in agreement with those by Gomaa et al., (2016) and Abdou (2017) who reported that the biological treatments increased the content of CP but decreased the content of cell wall components more than control.

Results of Table (3) showed that diets contained DPL after incubated with the combinations of enzymes with each other had higher disappearance of all nutrients. The highest values were recorded for the combination of Cellulase and Fibrolytic enzymes (D5) followed by the combination of cellulase and taninnase enzymes (D4) then the combination of taninnase and fibrolytic enzymes (D6). However diet contained DPL after incubated with taninnase enzyme had the lowest nutrients disappearance. The disappearance of $\mathrm{CP}$ was the same for $\mathrm{D} 5, \mathrm{D} 3$ and $\mathrm{D} 1$. The disappearance of $\mathrm{CF}$ and its fractions were higher in D5, D4 and D6 compared to D3, D1 and D2, and this indicates that the combination of enzymes was more effective in nutrients disappearance. These results indicate the possibility of using DPL diets incubated with cellulase and fibrolytic enzymes and combinations with each other in the digestibility trails. 
Table (2): Chemical composition and cell wall constituents (\%) of in vitro trail diets contained date palm leaves after incubation with enzymes.

\begin{tabular}{|c|c|c|c|c|c|c|c|}
\hline \multirow[t]{2}{*}{ Item } & \multicolumn{6}{|c|}{ Treatments } & \multirow[t]{2}{*}{$\pm \mathrm{SE}$} \\
\hline & D1 & D2 & D3 & D4 & D5 & D6 & \\
\hline \multicolumn{8}{|l|}{ Chemical composition\%: } \\
\hline DM & 93.56 & 93.26 & 93.37 & 93.41 & 93.77 & 93.31 & 0.066 \\
\hline $\mathrm{OM}$ & 92.24 & 91.97 & 92.21 & 92.12 & 92.64 & 91.94 & 0.042 \\
\hline Ash & 7.76 & 8.03 & 7.79 & 7.88 & 7.36 & 8.06 & 0.034 \\
\hline $\mathrm{EE}$ & 2.47 & 2.43 & 2.48 & 2.44 & 2.50 & 2.45 & 0.023 \\
\hline $\mathrm{CP}$ & 13.19 & 12.96 & 13.24 & 13.06 & 13.32 & 12.98 & 0.036 \\
\hline $\mathrm{CF}$ & 14.94 & 15.46 & 14.91 & 15.18 & 14.71 & 15.17 & 0.026 \\
\hline NFE & $61.64^{\mathrm{ab}}$ & $61.12^{\mathrm{ab}}$ & $61.58^{\mathrm{ab}}$ & $61.44^{\mathrm{ab}}$ & $62.11^{\mathrm{a}}$ & $61.34^{\mathrm{ab}}$ & 0.037 \\
\hline NFC & $38.97^{\mathrm{a}}$ & $38.39^{\mathrm{c}}$ & $39.28^{\mathrm{ab}}$ & 39.06 & $40.01^{\mathrm{a}}$ & $38.88^{\mathrm{b}}$ & 0.031 \\
\hline \multicolumn{8}{|l|}{ Cell wall constituents: } \\
\hline $\mathrm{NDF}$ & $37.61^{\mathrm{ab}}$ & $38.19^{\mathrm{a}}$ & $37.21^{\mathrm{ab}}$ & $37.56^{\mathrm{ab}}$ & $36.81^{\mathrm{b}}$ & $37.63^{\mathrm{ab}}$ & 0.046 \\
\hline $\mathrm{ADF}$ & $24.54^{\mathrm{ab}}$ & $25.05^{\mathrm{a}}$ & $24.29^{\mathrm{ab}}$ & $24.58^{\mathrm{ab}}$ & $23.87^{\mathrm{b}}$ & $24.46^{\mathrm{ab}}$ & 0.042 \\
\hline ADL & $7.41^{\mathrm{ab}}$ & $8.70^{\mathrm{a}}$ & $7.19^{\mathrm{ab}}$ & $7.58^{\mathrm{ab}}$ & $6.80^{\mathrm{b}}$ & $7.56^{\mathrm{ab}}$ & 0.034 \\
\hline Cellulose & $17.13^{\mathrm{a}}$ & $16.35^{\mathrm{b}}$ & $17.10^{\mathrm{a}}$ & $17.00^{\mathrm{a}}$ & $17.07^{\mathrm{a}}$ & $16.90^{\mathrm{a}}$ & 0.009 \\
\hline Hemicellulose & 13.07 & 13.14 & 12.92 & 12.98 & 12.94 & 13.17 & 0.009 \\
\hline
\end{tabular}

Means with different letters with each row are significantly different $(P \leq 0.01)$.

D (1): $50 \%$ CFM +40\% DPL incubated with Cellulase enzyme +10\% BH. D (2): $50 \%$ CFM +40\% DPL incubated with Taninnase enzyme $+10 \%$ BH. D (3): $50 \%$ CFM $+40 \%$ DPL incubated with Fibrolytic enzyme $+10 \%$ BH.

D (4): $50 \%$ CFM +40\% DPL incubated with Cellulase and Taninnase enzymes +10\% BH. D (5): $50 \%$ CFM +40\% DPL incubated with Cellulase and Fibrolytic enzymes +10\% BH. D (6): $50 \%$ CFM +40\% DPL incubated with Taninnase and Fibrolytic enzymes $+10 \% \mathrm{BH}$.

Table (3): In vitro nutrients disappearance (\%) of diets contained date palm leaves after incubation with enzymes.

\begin{tabular}{lcccccccc}
\hline \multirow{2}{*}{ Items } & \multicolumn{9}{c}{ Treatments } & \multirow{2}{*}{ \pm SE } & \multirow{2}{*}{ P value } \\
\cline { 2 - 7 } & D1 & D2 & D3 & D4 & D5 & D6 & & \\
\hline DM & $63.02^{\mathrm{e}}$ & $61.73^{\mathrm{f}}$ & $63.83^{\mathrm{d}}$ & $70.19^{\mathrm{b}}$ & $71.33^{\mathrm{a}}$ & $68.00^{\mathrm{c}}$ & 0.094 & 0.052 \\
OM & $54.29^{\mathrm{d}}$ & $51.96^{\mathrm{f}}$ & $53.37 \mathrm{e}$ & $58.59^{\mathrm{b}}$ & $60.76^{\mathrm{a}}$ & $56.10^{\mathrm{c}}$ & 0.094 & 0.052 \\
EE & $55.47^{\mathrm{e}}$ & $53.09^{\mathrm{f}}$ & $56.45^{\mathrm{d}}$ & $59.59^{\mathrm{b}}$ & $61.60^{\mathrm{a}}$ & $59.02^{\mathrm{c}}$ & 0.094 & 0.052 \\
$\mathrm{CP}$ & $70.58^{\mathrm{a}}$ & $69.14^{\mathrm{ab}}$ & $70.92^{\mathrm{a}}$ & $69.34^{\mathrm{ab}}$ & $70.42^{\mathrm{a}}$ & $68.07^{\mathrm{b}}$ & 0.094 & 0.052 \\
$\mathrm{CF}$ & $63.05^{\mathrm{e}}$ & $61.00^{\mathrm{f}}$ & $63.65^{\mathrm{d}}$ & $67.90^{\mathrm{b}}$ & $69.27^{\mathrm{a}}$ & $66.01^{\mathrm{c}}$ & 0.094 & 0.052 \\
NFE & $46.12^{\mathrm{e}}$ & $46.76^{\mathrm{d}}$ & $46.41^{\mathrm{e}}$ & $50.00^{\mathrm{b}}$ & $51.38^{\mathrm{a}}$ & $49.66^{\mathrm{c}}$ & 0.094 & 0.052 \\
NFC & $49.63^{\mathrm{d}}$ & $46.16^{\mathrm{f}}$ & $49.08^{\mathrm{e}}$ & $52.03^{\mathrm{b}}$ & $54.26^{\mathrm{a}}$ & $51.23^{\mathrm{c}}$ & 0.094 & 0.052 \\
NDF & $49.91^{\mathrm{e}}$ & $48.65^{\mathrm{f}}$ & $51.84^{\mathrm{d}}$ & $54.96^{\mathrm{b}}$ & $55.66^{\mathrm{a}}$ & $53.30^{\mathrm{c}}$ & 0.094 & 0.052 \\
ADF & $51.18^{\mathrm{d}}$ & $50.82^{\mathrm{f}}$ & $51.87^{\mathrm{c}}$ & $52.37^{\mathrm{b}}$ & $54.00^{\mathrm{a}}$ & $52.28^{\mathrm{b}}$ & 0.094 & 0.052 \\
ADL & $49.80^{\mathrm{e}}$ & $47.36^{\mathrm{f}}$ & $51.88^{\mathrm{d}}$ & $53.04^{\mathrm{b}}$ & $54.85^{\mathrm{a}}$ & $52.24^{\mathrm{c}}$ & 0.094 & 0.052 \\
Cellulose & $53.30^{\mathrm{d}}$ & $52.66^{\mathrm{f}}$ & $53.86^{\mathrm{c}}$ & $56.09^{\mathrm{b}}$ & $57.12^{\mathrm{a}}$ & $55.18^{\mathrm{c}}$ & 0.094 & 0.052 \\
Hemicellulose & $54.09^{\mathrm{e}}$ & $53.42^{\mathrm{f}}$ & $56.19^{\mathrm{d}}$ & $58.54^{\mathrm{b}}$ & $59.58^{\mathrm{a}}$ & $57.86^{\mathrm{c}}$ & 0.094 & 0.052 \\
\hline
\end{tabular}

Means with different letters with each row are significantly different $(P \leq 0.01)$.

The present results are coinciding with those obtained by Colombatto et al., (2003) who stated that fibrolytic enzymes enhanced the fermentation of cellulose. Gado and Abd El-Galil (2009) found that cellulase enzyme was effective in increasing the in vitro dry matter disappearance of bagasse. Khattab et $a l .$, (2012) stated that fibrolytic enzymes addition significantly increased IVDMD and IVOMD when they replacing corn with glycerol and fibrolytic enzymes. Aziz (2014) found that rations contained biologically treated sugar beet pulp with Sacharomyces cerevisiae or Trichoderma viride or Cellulomonas cellulase increased $(\mathrm{P} \leq 0.01)$ all nutrients disappearance. Also, Hanafy et al., (2015) reported that addition of fibrolytic enzymes $(4 \mathrm{~g} / \mathrm{kg} \mathrm{DM})$ for diets containing crude glycerol as a substitute for corn has a positive significant $(\mathrm{P}<0.05)$ effect on IVDMD and IVOMD compared with no additive treatment.

\section{Digestibility trails:}

Chemical composition of diets:

Data of Table (4) showed that diets contained DPL incubated with cellulase and fibrolytic enzymes and combinations with each other (D3, D4 and D5) showed higher ( $\mathrm{P} \leq 0.01) \mathrm{DM}, \mathrm{OM}, \mathrm{CP}, \mathrm{NFE}, \mathrm{NFC}$ 
and cellulose contents than both control diet (D1) and diet contained DPL without incubation with enzymes (D2). While CF, NDF, ADF, ADL and hemicellulose contents significantly $(\mathrm{P} \leq 0.01)$ decreased in diets comparing to D1 and D2.

Table (4): Chemical composition and cell wall constituents (\%) of the experimental diets.

\begin{tabular}{|c|c|c|c|c|c|c|c|c|}
\hline \multirow[t]{2}{*}{ Item } & & & \multicolumn{5}{|c|}{ Treatments } & \multirow[t]{2}{*}{$\pm \mathrm{SE}$} \\
\hline & CFM & Hay & D1 & D2 & D3 & D4 & D5 & \\
\hline \multicolumn{9}{|c|}{ Chemical composition: } \\
\hline $\mathrm{DM}$ & 93.42 & 91.08 & $92.28^{\mathrm{b}}$ & $93.18^{\mathrm{a}}$ & $93.56^{\mathrm{a}}$ & $93.37^{\mathrm{a}}$ & $93.77^{\mathrm{a}}$ & 0.046 \\
\hline $\mathrm{OM}$ & 92.11 & 88.06 & $90.20^{\mathrm{b}}$ & $91.13^{\mathrm{ab}}$ & $92.24^{\mathrm{a}}$ & $92.21^{\mathrm{a}}$ & $92.64^{\mathrm{a}}$ & 0.042 \\
\hline Ash & 7.89 & 11.94 & $9.80^{\mathrm{a}}$ & $8.87^{b}$ & $7.76^{\mathrm{c}}$ & $7.79^{c}$ & $7.36^{\mathrm{c}}$ & 0.024 \\
\hline $\mathrm{EE}$ & 2.96 & 2.42 & 2.67 & 2.24 & 2.47 & 2.48 & 2.50 & 0.053 \\
\hline $\mathrm{CP}$ & 12.33 & 13.74 & $13.00^{\mathrm{a}}$ & $9.96^{\mathrm{b}}$ & $13.19^{\mathrm{a}}$ & $13.24^{\mathrm{a}}$ & $13.32^{\mathrm{a}}$ & 0.022 \\
\hline $\mathrm{CF}$ & 11.16 & 26.32 & $18.71^{\mathrm{b}}$ & $24.9^{\mathrm{a}}$ & $14.94^{\mathrm{c}}$ & $14.91^{\mathrm{c}}$ & $14.71^{\mathrm{c}}$ & 0.072 \\
\hline NFE & 65.66 & 45.58 & $55.82^{\mathrm{b}}$ & $54.03^{\mathrm{c}}$ & $61.64^{\mathrm{a}}$ & $61.58^{\mathrm{a}}$ & $62.11^{\mathrm{a}}$ & 0.027 \\
\hline NFC & 46.18 & 9.53 & $28.05^{\mathrm{d}}$ & $33.35^{\mathrm{c}}$ & $38.97^{\mathrm{b}}$ & $39.28^{\mathrm{ab}}$ & $40.01^{\mathrm{a}}$ & 0.021 \\
\hline \multicolumn{9}{|c|}{ Cell wall constituents: } \\
\hline NDF & 30.64 & 62.37 & $46.48^{\mathrm{a}}$ & $45.58^{\mathrm{a}}$ & $37.61^{\mathrm{b}}$ & $37.21^{\mathrm{b}}$ & $36.81^{\mathrm{b}}$ & 0.036 \\
\hline $\mathrm{ADF}$ & 17.23 & 43.8 & $45.58^{\mathrm{a}}$ & $30.26^{\mathrm{b}}$ & $24.54^{\mathrm{b}}$ & $24.29^{\mathrm{b}}$ & $23.87^{\mathrm{b}}$ & 0.052 \\
\hline $\mathrm{ADL}$ & 7.70 & 7.00 & $7.32^{b}$ & $13.62^{\mathrm{a}}$ & $7.41^{b}$ & $7.19^{b}$ & $6.80^{c}$ & 0.054 \\
\hline Cellulose & 9.53 & 36.80 & $13.62^{\mathrm{c}}$ & $16.64^{\mathrm{b}}$ & $17.13^{\mathrm{a}}$ & $17.10^{\mathrm{a}}$ & $17.07^{\mathrm{a}}$ & 0.019 \\
\hline Hemicellulose & 13.41 & 18.57 & $16.64^{\mathrm{a}}$ & $15.32^{\mathrm{b}}$ & $13.07^{\mathrm{c}}$ & $12.92^{\mathrm{c}}$ & $12.94^{\mathrm{c}}$ & 0.010 \\
\hline
\end{tabular}

Means with different letters with each row are significantly different $(P \leq 0.01)$.

$D(1): 50 \% C F M+50 \% B H$ (control). D (2): $50 \% C F M+40 \% D P L+10 \% B H . \quad D(3): 50 \% C F M+40 \% D P L$ incubated with Cellulase enzyme $+10 \%$ BH. D (4): $50 \%$ CFM +40\% DPL incubated with fibrolytic enzyme $+10 \%$ BH. D (5): $50 \%$ CFM +40\% DPL incubated with Cellulase and fibrolytic enzymes $+10 \% \mathrm{BH}$.

\section{Feed intake:}

Body weight was not significantly differed among sheep fed on the diets (Table 5). Diet contained DPL incubated with fibrolytic enzyme (D4) increased total feed intake and CFM (g/h/d) followed by control diet (D1) with no significant difference $(\mathrm{P} \leq 0.01)$ then $\mathrm{D} 3$ and D5. Also, D4 increased the intakes of dry matter, crud protein, organic matter, digestible OM intake and digestible OM fermented in the rumen, followed by control (D1), D5 and D3 with no significant difference $(\mathrm{P} \leq 0.01)$ among them. The lowest intakes was shown for diet contained DPL without incubation with enzymes (D2).

Table (5): Feed intake of Barki sheep fed on the experimental diets.

\begin{tabular}{llllllll}
\hline & \multicolumn{9}{c}{ Treatments } & \multirow{2}{*}{ \pm SE } & \multirow{2}{*}{ P value } \\
\cline { 2 - 6 } Item & D1 & D2 & D3 & D4 & D5 & & \\
\hline Number of animals & 4 & 4 & 4 & 4 & 4 & & \\
Live body weight & 50.55 & 49.47 & 50.32 & 50.42 & 51.22 & 0.882 & 0.104 \\
Total feed intake g/h/d & $1076.88^{\mathrm{ab}}$ & $965.00^{\mathrm{c}}$ & $1027.50^{\mathrm{b}}$ & $1100.00^{\mathrm{a}}$ & $1042.50^{\mathrm{b}}$ & 16.44 & 0.200 \\
CFM g/h/d & $538.44^{\mathrm{ab}}$ & $482.50^{\mathrm{c}}$ & $513.75^{\mathrm{b}}$ & $550.00^{\mathrm{a}}$ & $521.25^{\mathrm{b}}$ & 8.22 & 0.200 \\
Hay g/h/d & $538.44^{\mathrm{a}}$ & $96.50^{\mathrm{e}}$ & $102.75^{\mathrm{d}}$ & $110.00^{\mathrm{b}}$ & $104.25^{\mathrm{c}}$ & 2.46 & 0.200 \\
Date palm leaves g/h/d & 0.00 & $386.00^{\mathrm{d}}$ & $411.00^{\mathrm{c}}$ & $440.00^{\mathrm{a}}$ & $417.00^{\mathrm{b}}$ & 5.75 & 0.200 \\
DMI g/h/d & $993.74^{\mathrm{b}}$ & $899.19^{\mathrm{e}}$ & $961.33^{\mathrm{d}}$ & $1027.07^{\mathrm{a}}$ & $977.55^{\mathrm{c}}$ & 15.39 & 0.202 \\
CPI g/h/d & $129.19^{\mathrm{b}}$ & $89.56^{\mathrm{d}}$ & $127.05^{\mathrm{c}}$ & $135.99^{\mathrm{a}}$ & $130.21^{\mathrm{ab}}$ & 1.96 & 0.211 \\
OMI g/h/d & $896.35^{\mathrm{b}}$ & $819.43^{\mathrm{d}}$ & $886.73^{\mathrm{c}}$ & $947.06^{\mathrm{a}}$ & $905.60^{\mathrm{b}}$ & 14.21 & 0.205 \\
DOMI g/h/d & $641.91^{\mathrm{bc}}$ & $543.92^{\mathrm{d}}$ & $630.56^{\mathrm{c}}$ & $686.94^{\mathrm{a}}$ & $664.72^{\mathrm{b}}$ & 14.12 & 0.352 \\
DOMR g/h/d & $417.24^{\mathrm{b}}$ & $353.55^{\mathrm{d}}$ & $409.86^{\mathrm{c}}$ & $446.51^{\mathrm{a}}$ & $432.07^{\mathrm{ab}}$ & 9.18 & 0.352 \\
\hline
\end{tabular}

Means with different letters with each row are significantly different $(P \leq 0.01)$.

*Digestible OM intake. ** Digestible OM fermented in the rumen, calculated as $0.65 \times D O M$ intake (ARC,1984).

Enzymes supplementation to ration is often accompanied by increased feed intake, which may partly be due to increased palatability of the diet due to sugars released by pre-digestive fiber hydrolysis. However, post-digestive enzyme effects as increasing digestion rate and extent of digestion (Krueger Adesogan, 2008) may increase hydrolytic activity in the rumen to reduce gut fill and enhance feed intake (Adesogan, 2005). 
The present results agree with those reported by Stella et al. (2007) and Gado et al. (2009) who found that dairy cows fed forage treated with a fibrolytic enzyme additive consumed more feed and produced 525\% more milk. Abdou (2017) found that sheep fed diet contained olive cake treated with enzyme recorded higher feed intake than those fed control.

\section{Coefficients of digestibility and nutritive values:}

Diets of DPL incubated with cellulase and fibrolytic enzymes and combinations with each other (D3, D4 and D5) enhanced digestibility coefficients for all nutrients compared to diet contained DPL without incubation with enzymes (D2) (table 6), the difference among the diets were significant (P $\leq 0.01)$ as D5 was the best one followed by D4 then D3 while D2 was the lowest one. Control diet (D1) had the highest digestibility coefficients of EE, CP and NFE among all other diets. Also, D1 had the highest digestibility coefficients of ADF, ADL, cellulose and hemicellulose followed by D5 with no significant difference between them. The values of digestibility coefficients were higher than the values of in vitro nutrients disappearance for all nutrients, except for CP digestibility which was less for diets contained DPL. These may be related to the higher content of ruminal fluid and the ruminal microbes in the animal.

Table (6): Digestibility coefficients of and nutritive values of the different experimental diets.

\begin{tabular}{llllllll}
\hline Item & \multicolumn{5}{c}{ Treatments } & \multirow{2}{*}{ \pm SE } & P value \\
\cline { 2 - 6 } & D1 & D2 & D3 & D4 & D5 & & \\
\hline Digestibility\%: & & & & & & & \\
DM & $71.34^{\mathrm{b}}$ & $64.18^{\mathrm{d}}$ & $70.12^{\mathrm{c}}$ & $71.52^{\mathrm{b}}$ & $72.43^{\mathrm{a}}$ & 0.723 & 0.247 \\
OM & $71.60^{\mathrm{c}}$ & $66.35^{\mathrm{d}}$ & $71.10^{\mathrm{c}}$ & $72.50^{\mathrm{b}}$ & $73.41^{\mathrm{a}}$ & 0.723 & 0.243 \\
EE & $67.77^{\mathrm{a}}$ & $58.69^{\mathrm{e}}$ & $60.69^{\mathrm{d}}$ & $64.51^{\mathrm{c}}$ & $65.99^{\mathrm{b}}$ & 1.006 & 0.655 \\
CP & $70.41^{\mathrm{a}}$ & $51.87^{\mathrm{d}}$ & $58.53^{\mathrm{c}}$ & $59.91^{\mathrm{b}}$ & $59.95^{\mathrm{b}}$ & 2.231 & 0.390 \\
CF & $69.46^{\mathrm{d}}$ & $66.80^{\mathrm{e}}$ & $70.07^{\mathrm{c}}$ & $71.05^{\mathrm{b}}$ & $72.11^{\mathrm{a}}$ & 0.889 & 0.810 \\
NFE & $66.32^{\mathrm{a}}$ & $54.66^{\mathrm{e}}$ & $60.40^{\mathrm{d}}$ & $61.84^{\mathrm{c}}$ & $62.17^{\mathrm{b}}$ & 2.339 & 0.262 \\
NFC & $73.02^{\mathrm{c}}$ & $66.29^{\mathrm{d}}$ & $73.83^{\mathrm{b}}$ & $73.87^{\mathrm{b}}$ & $75.18^{\mathrm{a}}$ & 1.490 & 0.162 \\
NDF & $73.29^{\mathrm{d}}$ & $72.96^{\mathrm{e}}$ & $74.57^{\mathrm{c}}$ & $75.19^{\mathrm{b}}$ & $77.38^{\mathrm{a}}$ & 4.478 & 0.288 \\
ADF & $58.52^{\mathrm{a}}$ & $54.00^{\mathrm{d}}$ & $56.96^{\mathrm{c}}$ & $57.66^{\mathrm{b}}$ & $58.12^{\mathrm{ab}}$ & 1.283 & 0.563 \\
ADL & $61.38^{\mathrm{a}}$ & $51.82^{\mathrm{d}}$ & $56.48^{\mathrm{c}}$ & $58.15^{\mathrm{b}}$ & $61.16^{\mathrm{a}}$ & 1.612 & 0.675 \\
Cellulose & $60.42^{\mathrm{a}}$ & 51.66 & 55.97 & 56.72 & $58.66^{\mathrm{a}}$ & 2.160 & 0.040 \\
Hemicellulose & $61.97^{\mathrm{a}}$ & $50.23^{\mathrm{e}}$ & $54.16^{\mathrm{d}}$ & $55.28^{\mathrm{c}}$ & $57.36^{\mathrm{b}}$ & 2.318 & 0.622 \\
Nutritive value: & & & & & & \\
TDN \% of DM & $67.05^{\mathrm{a}}$ & $62.04^{\mathrm{b}}$ & $67.11^{\mathrm{a}}$ & $66.81^{\mathrm{a}}$ & $68.37^{\mathrm{a}}$ & 0.829 & 0.041 \\
DCP\% of DM & $9.03^{\mathrm{c}}$ & $6.65^{\mathrm{d}}$ & $9.24^{\mathrm{bc}}$ & $9.40^{\mathrm{ab}}$ & $9.60^{\mathrm{a}}$ & 0.108 & 0.788 \\
DE (Mcal kg DM) & $2.95^{\mathrm{a}}$ & $2.73^{\mathrm{b}}$ & $2.96^{\mathrm{a}}$ & $2.94^{\mathrm{a}}$ & $3.01^{\mathrm{a}}$ & 0.036 & 0.037 \\
ME (Mcal kg DM) & $2.41^{\mathrm{ab}}$ & $2.02^{\mathrm{c}}$ & $2.33^{\mathrm{b}}$ & $2.48^{\mathrm{a}}$ & $2.41^{\mathrm{ab}}$ & 0.031 & 0.009 \\
\hline
\end{tabular}

Means with different letters with each row are significantly different $(P \leq 0.01)$.

$* D E=$ Digestible energy $=T D N \% \times 0.04409$ (Crampton, et al., 1957).

$* * M E=$ Metabolic energy $=T D N$ g/head $\times 3.6$ (Church and Pond, 1982).

The data of Table (6) showed that diet contained DPL without incubation with enzymes (D2) was less $(\mathrm{P} \leq 0.01)$ nutritive values as TDN and DCP $(\%$ of DM) compared to diets contained DPL incubated with enzymes (D3, D4 and D5). Also, D4 increased TDN and DCP values followed by D5 then D3. Control diet (D1) had high values of TDN (\%), where the difference among D1, D5, D4 and D3 was not significant $(\mathrm{P} \leq 0.01)$, while D1 had lower values of DCP $(\%)$ than D5, D4 and D3.

The highest digestible energy (Mcal kg DM) was for D5, while the highest metabolic energy (Mcal kg DM) was for D4, while D2 had the lowest DE and ME values.

The enhancement in digestibility coefficients due to exogenous enzymes may be due to increasing the microbial colonization of feed particles (Yang et al., 1999), or due to enhancing attachment and /or improve access to the wall matrix by ruminal microorganisms which result in accelerating the rate of digestion (Nsereko et al., 2000).

The present results are agreement with those obtained by Yang et al., (1999) and Kung et al., (2000) who reported that exogenous feed fibrolytic enzymes could enhance fiber digestion in the rumen. A commercial exogenous enzyme mixture (Zad1), prepared from anaerobic bacterium, has been shown to improve nutrient digestibility and nutritive values (Gado et al., 2007 and Soliman, 2006). Also, Khattab et al., (2012) stated that fibrolytic enzymes improved nutrient digestibilies of DM, OM, CP, NDF and ADF. Aziz (2014 and 2015) found an increase in nutrient digestibility and nutritive values (TDN and DCP) with 
biological treatments for agricultural residues more than control and untreated diet. Abdou (2017) reported that diets contained crop by- products as olive cake in treated with enzyme significantly $(\mathrm{p}<0.01)$ improved nutrients digestibilities, TDN and DCP values for sheep compared to control diet. Moreover, DeFrain et al., (2005) found that exogenous enzyme improved the energy balance of dairy cows

\section{Nitrogen utilization:}

Diets contained DPL incubated with enzymes (D4, D5 and D3; respectively) significantly $(\mathrm{P} \leq 0.01)$ increased nitrogen intake $(\mathrm{g} / \mathrm{h} / \mathrm{d})$ and digested nitrogen $(\mathrm{g} / \mathrm{h} / \mathrm{d}$ and $\%$ of $\mathrm{NI})$ values compared to D2 (without incubation with enzymes) (table 7). The increase was about 7.42, 6.5 and 5.99 (NI) g/h/d and

Table (7): Utilization of nitrogen by Barki sheep fed on the experimental diets.

\begin{tabular}{|c|c|c|c|c|c|c|c|}
\hline \multirow[t]{2}{*}{ Item } & \multicolumn{5}{|c|}{ Treatments } & \multirow[t]{2}{*}{ \pm SE } & \multirow[t]{2}{*}{$P$ value } \\
\hline & D1 & D2 & D3 & D4 & D5 & & \\
\hline Nitrogen intake $\mathrm{g} / \mathrm{h} / \mathrm{d}$ & $20.67^{b}$ & $14.33^{\mathrm{c}}$ & $20.32^{b}$ & $21.75^{\mathrm{a}}$ & $20.83^{\mathrm{ab}}$ & 0.313 & 0.211 \\
\hline \multicolumn{8}{|l|}{ Digested nitrogen } \\
\hline $\mathrm{g} / \mathrm{h} / \mathrm{d}$ & $14.36^{\mathrm{b}}$ & $9.57^{\mathrm{c}}$ & $14.21^{\mathrm{b}}$ & $15.46^{\mathrm{a}}$ & $15.03^{\mathrm{a}}$ & 0.365 & 0.705 \\
\hline$\%$ of $\mathrm{N}$ intake & $69.46^{\mathrm{c}}$ & $66.80^{\mathrm{d}}$ & $69.92^{c}$ & $71.05^{\mathrm{b}}$ & $72.11^{\mathrm{a}}$ & 0.893 & 0.013 \\
\hline \multicolumn{8}{|l|}{ Fecal nitrogen } \\
\hline $\mathrm{g} / \mathrm{h} / \mathrm{d}$ & $6.31^{\mathrm{a}}$ & $4.75^{\mathrm{c}}$ & $6.07^{\mathrm{ab}}$ & $6.29^{\mathrm{a}}$ & $5.80^{\mathrm{b}}$ & 0.125 & 0.131 \\
\hline$\%$ of $\mathrm{N}$ intake & $30.53^{\mathrm{ab}}$ & $33.19^{\mathrm{a}}$ & $29.87^{\mathrm{b}}$ & $28.94^{\mathrm{b}}$ & $27.88^{\mathrm{b}}$ & 0.888 & 0.012 \\
\hline \multicolumn{8}{|l|}{ Urinary nitrogen } \\
\hline $\mathrm{g} / \mathrm{h} / \mathrm{d}$ & $0.412^{\mathrm{ab}}$ & $0.432^{\mathrm{a}}$ & $0.405^{\mathrm{b}}$ & $0.387^{\mathrm{b}}$ & $0.352^{\mathrm{c}}$ & 0.008 & 0.053 \\
\hline$\%$ of $\mathrm{N}$ intake & $1.98^{\mathrm{b}}$ & $3.00^{\mathrm{a}}$ & $2.00^{\mathrm{b}}$ & $1.78^{\mathrm{c}}$ & $1.69^{c}$ & 0.050 & 0.122 \\
\hline \multicolumn{8}{|l|}{ Total $\mathrm{N}$ excretion } \\
\hline $\mathrm{g} / \mathrm{h} / \mathrm{d}$ & $6.72^{\mathrm{a}}$ & $5.18^{\mathrm{c}}$ & $6.47^{\mathrm{ab}}$ & $6.68^{\mathrm{a}}$ & $6.15^{\mathrm{b}}$ & 0.124 & 0.126 \\
\hline$\%$ of $\mathrm{N}$ intake & $32.52^{\mathrm{b}}$ & $36.20^{\mathrm{a}}$ & $31.87^{\mathrm{b}}$ & $30.72^{\mathrm{b}}$ & $29.58^{\mathrm{b}}$ & 0.908 & 0.822 \\
\hline \multicolumn{8}{|l|}{ Nitrogen balance } \\
\hline $\mathrm{g} / \mathrm{h} / \mathrm{d}$ & $13.94^{\mathrm{ab}}$ & $9.14^{\mathrm{c}}$ & $13.84^{\mathrm{b}}$ & $15.07^{\mathrm{a}}$ & $14.68^{\mathrm{ab}}$ & 0.362 & 0.701 \\
\hline$\%$ of $\mathrm{N}$ intake & $67.47^{\mathrm{a}}$ & $63.79^{b}$ & $68.12^{\mathrm{a}}$ & $69.27^{\mathrm{a}}$ & $70.41^{\mathrm{a}}$ & 0.908 & 0.822 \\
\hline$\%$ of digested $\mathrm{N}$ & $97.13^{\mathrm{b}}$ & $95.49^{c}$ & $97.42^{\mathrm{ab}}$ & $97.49^{\mathrm{ab}}$ & $97.64^{\mathrm{a}}$ & 0.138 & 0.828 \\
\hline
\end{tabular}

Means with different letters with each row are significantly different $(P \leq 0.01)$.

5.89, 5.46 and $4.64(\mathrm{DN}) \mathrm{g} / \mathrm{h} / \mathrm{d}$ for $\mathrm{D} 4, \mathrm{D} 5$ and D3; respectively. Non-significant $(\mathrm{P} \leq 0.01)$ differences were found between D5 and D3 for NI and DN values, although D1 had higher fecal nitrogen excretion $(\mathrm{g} / \mathrm{h} / \mathrm{d}$ and $\%$ of $\mathrm{NI})$ followed by D4 and D3 then D4 with no significant $(\mathrm{P} \leq 0.01)$ differences among them. Also, differences among them were not significant $(\mathrm{P} \leq 0.01)$ for total $\mathrm{N}$ excretion and nitrogen balance. Diet contained DPL without incubation with enzymes (D2) had the lowest $(\mathrm{P} \leq 0.01)$ value of $F N$ $(\mathrm{g} / \mathrm{h} / \mathrm{d})$, although it had the highest $(\mathrm{P} \leq 0.01)$ values of $\mathrm{UN}(\mathrm{g} / \mathrm{h} / \mathrm{d}$ and $\%$ of $\mathrm{NI})$, this reflected on total nitrogen excretion values as that $\mathrm{D} 2$ was the lowest $(\mathrm{P} \leq 0.01)$ total $\mathrm{N}$ excretion value $(\mathrm{g} / \mathrm{h} / \mathrm{d})$, while it had the highest $(\mathrm{P} \leq 0.01)$ value as \% of NI. Also as $\mathrm{D} 2$ was the lowest NI and DN, it decreased nitrogen utilization by $5.24(\mathrm{~g} / \mathrm{h} / \mathrm{d})$ from other diets. The highest nitrogen utilization was for D4 with no significant $(\mathrm{P} \leq 0.01)$ deference with control diet and other enzymatic diets.

The present results are paralleled with those reported by Allam et al., (2006) who showed that biological treatment with $T$. viride and $S$. cerevisiae had the highest value of nitrogen balance and NB/IN in diets contained sugar beet pulp. Gado et al., (2007) and Soliman, (2006) used a commercial exogenous enzyme mixture (Zad1), prepared from anaerobic bacterium for crop residues, they indicated an improvement in N balance for ruminants. Moreover, Aziz (2014 and 2015) found an increase in nitrogen balance of sheep and goats fed biologically treated sugar beet pulp.

\section{Urinary purine derivatives (PD) and microbial nitrogen supply:}

Feeding diets contained DPL incubated with enzymes significantly $(\mathrm{P} \leq 0.01)$ increased allantion, uric acid, xanthine and hypoxanthine, total microbial purines (PD) (mmol/day) and microbial nitrogen supply ( $\mathrm{g} / \mathrm{d}$ and $\mathrm{g} / \mathrm{Kg}$ of DOMR) compared to control diet or diet contained DPL without incubation with enzymes. The highest values were recorded for D5 followed by D4 then D3, while D2 had the lowest values. Similar results were obtained by Khattab et al., (2013) for sheep fed date by-products. 
Egyptian J. Nutrition and Feeds (2020)

Table (8): Urinary purine derivatives (PD) and microbial nitrogen supply by Barki sheep fed on the experimental diets.

\begin{tabular}{|c|c|c|c|c|c|c|c|}
\hline \multirow[t]{2}{*}{ Item } & \multicolumn{5}{|c|}{ Treatments } & \multirow[t]{2}{*}{$\pm \mathrm{SE}$} & \multirow[t]{2}{*}{$P$ value } \\
\hline & D1 & D2 & D3 & D4 & D5 & & \\
\hline Allantion (mmol/day) & $5.61^{b}$ & $4.96^{\mathrm{c}}$ & $6.18^{\mathrm{a}}$ & $6.26^{\mathrm{a}}$ & $6.37^{\mathrm{a}}$ & 0.06 & 0.648 \\
\hline Uric acid (mmol/day) & $1.51^{\mathrm{d}}$ & $1.41^{\mathrm{e}}$ & $1.62^{\mathrm{c}}$ & $1.68^{\mathrm{b}}$ & $1.74^{\mathrm{a}}$ & 0.01 & 0.199 \\
\hline $\begin{array}{l}\text { Xanthine and Hypoxanthine } \\
\text { (mmol/day) }\end{array}$ & $0.67^{\mathrm{b}}$ & $0.53^{\mathrm{c}}$ & $0.71^{\mathrm{ab}}$ & $0.73^{\mathrm{a}}$ & $0.75^{\mathrm{a}}$ & 0.01 & 0.750 \\
\hline $\begin{array}{l}\text { Total microbial purines (PD) } \\
\text { (mmol/day) } \\
\text { microbial nitrogen supply }\end{array}$ & $7.79^{c}$ & $6.90^{\mathrm{d}}$ & $8.52^{\mathrm{b}}$ & $8.68^{\mathrm{ab}}$ & $8.87^{\mathrm{a}}$ & 0.06 & 0.385 \\
\hline $\mathrm{g} / \mathrm{d}$ & $5.66^{\mathrm{c}}$ & $5.02^{\mathrm{d}}$ & $6.19^{\mathrm{b}}$ & $6.31^{\mathrm{ab}}$ & $6.44^{\mathrm{a}}$ & 0.04 & 0.388 \\
\hline $\mathrm{g} / \mathrm{Kg}$ of DOMR* & $13.59^{\mathrm{b}}$ & $14.23^{\mathrm{ab}}$ & $15.14^{\mathrm{a}}$ & $14.15^{\mathrm{ab}}$ & $14.94^{\mathrm{a}}$ & 0.33 & 0.259 \\
\hline
\end{tabular}

Means with different letters with each row are significantly different $(P \leq 0.01)$.

*Digestible OM fermented in the rumen.

The energy derived from carbohydrates digestion in many instances is the primary determinant of microbial growth. Accordingly, Allantion and microbial $\mathrm{N}$ were decreased consistently with decreasing of OM, NDF and ADF digestibilities. Increased OM intake and OM apparently digested in the rumen have been reported to increase microbial production (Clark et al., 1992). The increased in microbial production can be attributed at least partially to the larger amount of energy supplied by the larger quantity of OM fermented in the rumen (Chen et al., 1992).

The present results suggest that efficiency of microbial nitrogen synthesis based on fermented OM in the rumen was affected by the experimental diets. The values ranged from 13.59 to $15.14 \mathrm{~g} \mathrm{~N} / \mathrm{Kg}$ DOMR, these values are near to these (14 to $49 \mathrm{~g} \mathrm{~N} / \mathrm{Kg}$ DOMR) reported by ARC (1984). Variability in efficiency of microbial $\mathrm{N}$ Synthesis exists as a result of various factors like concentration and sources of nitrogen and carbohydrates.

\section{Parameters of rumen:}

Feeding diets contained DPL incubated with enzymes (D5, D4 and D3) and control diet (D1) increased $(\mathrm{P} \leq 0.01)$ ruminal $\mathrm{pH}$ values compared with diet with no enzyme (D2) (Table 9). The values of ruminal $\mathrm{pH}$ were within the physiological range of 6.0-7.0 which have no negative effect on bacterial growth (Hoover, 1986). Moreover, total volatile fatty acids, total nitrogen, true protein, non-protein nitrogen, ammonia nitrogen and microbial protein concentrations $(\mathrm{mg} / 100 \mathrm{mlR} . \mathrm{L})$ significantly $(\mathrm{P} \leq 0.01)$ increased by feeding diets with enzymes compared with control and non-enzymatic diets (Table 9), the highest values was recorded for D5 followed by D4 then D3, while D2 had the lowest concentrations. The differences among the diets contained DPL incubated with enzymes (D5, D4 and D3) were not significant for the concentrations of $\mathrm{pH}, \mathrm{TN}$ and $\mathrm{MP}$, although the differences among them were significant $(\mathrm{P} \leq 0.01)$ for the concentrations of TVFA's, TP, NPN and NH3-N. The overall means of all rumen parameters (except $\mathrm{pH}$ ) and microbial protein concentrations at different sampling times showed a significant increase $(\mathrm{P} \leq 0.01)$ after feeding to reach the highest $(\mathrm{P} \leq 0.01)$ values after $4 \mathrm{hrs}$ post-feeding. The overall means of ruminal $\mathrm{pH}$ at the different sampling times were at the inverse site of other rumen parameters as it showed a significant decrease $(\mathrm{P} \leq 0.01)$ after $4 \mathrm{hrs}$ post-feeding although it was high per-feeding. In general, the rumen $\mathrm{pH}$ decreased with increasing the TVFA's concentration (Fouad, 1991). El-Ashry et al. (1997) reported that the minimum $\mathrm{pH}$ values were observed at $3 \mathrm{~h}$ post-feeding, but the maximum concentration of total VFAs was observed at $3 \mathrm{~h}$ post-feeding with fungal ( $\mathrm{P}$. funiculisms) treated rice straw. The increase in VFA are likely due to enhanced ruminal fermentation by the increased $\mathrm{pH}$ with biological treatments or might be a result of altered rumen microbial populations and increase of microbial activity (Aziz, 2004).

The reduction of rumen $\mathrm{pH}$ after feeding of diets treated with enzymes could be attributed to the major role of protozoa in slowing down the fermentation by ingesting starch grains and taking up soluble sugars and converting them to storage polysaccharides (Williams and Coleman, 1997). 
Table (9): Rumen parameters for Barki sheep fed on the experimental diets.

\begin{tabular}{|c|c|c|c|c|c|c|c|c|}
\hline \multirow[t]{2}{*}{ Item } & \multirow[t]{2}{*}{ Time } & \multicolumn{5}{|c|}{ Treatment } & \multirow[t]{2}{*}{$\pm \mathrm{SE}$} & \multirow[t]{2}{*}{ Overall mean } \\
\hline & & D1 & D2 & D3 & D4 & D5 & & \\
\hline \multirow[t]{2}{*}{$\mathrm{pH}$} & 0 & 7.34 & 6.85 & 7.16 & 7.31 & 7.37 & 0.05 & $7.20^{\mathrm{a}} \pm 0.02$ \\
\hline & 4 & 6.30 & 6.17 & 6.38 & 6.46 & 6.59 & 0.05 & $6.38^{\mathrm{b}} \pm 0.02$ \\
\hline Overall mean & & $6.82^{\mathrm{ab}}$ & $6.51^{\mathrm{c}}$ & $6.77^{b}$ & $6.89^{\mathrm{ab}}$ & $6.98^{\mathrm{a}}$ & 0.03 & \\
\hline TVFA's & 0 & 8.57 & 8.13 & 9.02 & 9.14 & 9.27 & 0.10 & $8.83^{\mathrm{b}} \pm 0.04$ \\
\hline equiv/100 ml R.L & 4 & 10.52 & 9.94 & 12.28 & 12.41 & 12.86 & 0.10 & $11.60^{\mathrm{a}} \pm 0.04$ \\
\hline Overall mean & & $9.55^{\mathrm{c}}$ & $9.03^{\mathrm{d}}$ & $10.65^{\mathrm{b}}$ & $10.77^{\mathrm{b}}$ & $11.06^{\mathrm{a}}$ & 0.07 & \\
\hline nitrogen & 0 & 98.28 & 88.96 & 110.62 & 113.50 & 116.35 & 2.44 & $105.54^{\mathrm{b}} \pm 1.09$ \\
\hline mg/100 ml R.L & 4 & 121.62 & 112.56 & 131.74 & 132.55 & 137.99 & 2.44 & $127.29^{\mathrm{a}} \pm 1.09$ \\
\hline Overall mean & & $109.95^{\mathrm{d}}$ & $100.76^{\mathrm{e}}$ & $121.18^{\mathrm{c}}$ & $123.02^{\mathrm{b}}$ & $127.17^{\mathrm{a}}$ & 1.72 & \\
\hline True protein & 0 & 32.62 & 43.04 & 41.84 & 44.32 & 61.34 & 1.81 & $39.75^{\mathrm{b}} \pm 0.81$ \\
\hline $\begin{array}{l}\text { nitrogen } \mathrm{mg} / 100 \mathrm{ml} \\
\text { R.L }\end{array}$ & 4 & 39.08 & 49.42 & 47.48 & 47.63 & 78.07 & 1.81 & $45.43^{\mathrm{a}} \pm 0.81$ \\
\hline Overall mean & & $40.245^{\mathrm{b}}$ & $35.85^{\mathrm{c}}$ & $46.23^{\mathrm{a}}$ & $44.66^{\mathrm{a}}$ & $45.98^{\mathrm{a}}$ & 1.28 & \\
\hline \multirow[t]{2}{*}{ NPN mg/100 ml R.L } & 0 & 67.58 & 71.65 & 72.02 & 30.64 & 27.95 & 2.59 & $65.79^{\mathrm{b}} \pm 1.15$ \\
\hline & 4 & 82.32 & 85.07 & 90.35 & 36.22 & 33.46 & 2.59 & $81.86^{\mathrm{a}} \pm 1.15$ \\
\hline Overall mean & & $69.71^{\mathrm{d}}$ & $64.91^{\mathrm{e}}$ & $74.95^{\mathrm{c}}$ & $78.36^{\mathrm{b}}$ & $81.19^{\mathrm{a}}$ & 1.83 & \\
\hline Ammonia nitrogen & 0 & 30.64 & 27.95 & 32.56 & 33.77 & 37.11 & 0.50 & $32.41^{\mathrm{b}} \pm 0.22$ \\
\hline mg/ 100 ml R.L & 4 & 36.22 & 33.46 & 37.86 & 39.04 & 43.57 & 0.50 & $38.03^{\mathrm{a}} \pm 0.22$ \\
\hline Overall mean & & $33.43^{\mathrm{d}}$ & $30.70^{\mathrm{e}}$ & $35.21^{\mathrm{c}}$ & $36.40^{\mathrm{b}}$ & $40.34^{\mathrm{a}}$ & 0.35 & \\
\hline Microbial protein & 0 & 65.46 & 60.26 & 69.98 & 70.87 & 74.35 & 3.27 & $68.18^{\mathrm{b}} \pm 1.46$ \\
\hline $\mathrm{mg} / 100 \mathrm{mlRL}$ & 4 & 108.98 & 97.65 & 113.28 & 115.9 & 120.92 & 3.27 & $111.35^{\mathrm{a}} \pm 1.46$ \\
\hline Overall mean & & $87.22^{\mathrm{c}}$ & $78.95^{\mathrm{d}}$ & $91.63^{\mathrm{b}}$ & $93.41^{\mathrm{ab}}$ & $97.63^{\mathrm{a}}$ & 2.31 & \\
\hline
\end{tabular}

Means with different letters with each row are significantly different $(P \leq 0.01)$.

$p H(P=0.173), T V F A ' s(P=0.081), T N(P=0.022), T P(P=0.594), N P N(P=0.078), A m(P=0.028), M P(P=$ $0.318)$.

The increase in TN, TP, NPN, NH3-N and microbial protein concentrations (table 9) may be due to the increase in crude protein content and decrease in fiber content which led to the increase in digestibility coefficients of all nutrients, or may be due to the improvement in microbial population in the rumen which plays an important role in rumen fermentation. Coleman (1980) reported that, increase rumen $\mathrm{NH} 3-\mathrm{N}$ concentration is often associated with the presence of protozoa. Also, microbial protein plays an important role as it's analyzed in the abomasum and small intestine by enzymes to produce free amino acids which absorbed in the small intestine and used by the animal in production of meet or milk (Aziz, 2009). Moreover, Beever and Siddons, (1986) reported that microbial protein synthesized in the rumen accounts between 50 and $90 \%$ of the protein entering the small intestine in ruminants.

The present results are supported by the results obtained by El-Ashry et al., (1997) who reported that the minimum $\mathrm{pH}$ values were observed at $3 \mathrm{~h}$ post-feeding (ranged between 6.29 and 6.83) with fungal ( $\mathrm{P}$. funiculisms) treated rice straw, while the maximum concentration of total VFAs were observed at $3 \mathrm{~h}$ post-feeding. Yang et al., (1999) and Nsereko et al., (2002) found that feeding enzymes enhanced rumen microbial protein synthesis. McAllister et al. (2001) reported that exogenous enzymes may affect overall fermentation and end-product formation in the rumen. Also, Soliman, (2006) and Gado et al., (2007) reported that using exogenous enzymes mixture for crop residues enhanced rumen fermentations for ruminants. Moreover, Kholif and Aziz (2014) found that addition of cellulytic enzymes in the diet of goats decreased ruminal pH, while TVFA's, TN, TP, NPN, NH3-N and microbial protein concentrations were significant $(\mathrm{P}<0.01)$ increase, also they showed a significant $(\mathrm{P}<0.01)$ decrease in ruminal $\mathrm{pH}$ by time of feeding, although other parameters reached the highest $(\mathrm{P}<0.01)$ values at $4 \mathrm{~h}$ post-feeding.

\section{Identification and density of ruminal ciliate protozoa species:}

Entodinum spp. Epidinium spp., Diplodinum spp., Ophryoscolox spp., Polyolastron spp., Isotrchia spp. and Dasytrachia spp. were the species of ruminal protozoa that identified in the ruminal fluid of sheep fed control diet or diets contained DPL incubated or not with enzymes (Table10). Differential and total numbers of ruminal ciliate protozoa species ( $\times 10^{4}$ cell/ml rumen liquor) were significant increased $(\mathrm{P} \leq 0.01)$ by feeding diets contained DPL incubated with enzymes (D3, D4 and D5), as D5 was the highest one followed by D4 then D3, although differences were non-significant. Diet received no enzymes had the lowest counts for ruminal ciliate protozoa with significant $(\mathrm{P} \leq 0.01)$ difference except for Epidinium and Dasytrachia spps. Control diet (D1) showed non-significant $(\mathrm{P} \leq 0.01)$ difference with non or enzymatic diets for numbers of Epidinium, Diplodinum, Isotrchia and Dasytrachia spps., which 
indicated that diets contained DPL incubated or not with enzymes were efficient as the control ration which contained hay only. Entodinum spp. had the most appearance among all differential kinds of ciliate protozoa species. Counts of total and differential ciliate protozoa at different sampling times were significant increased $(\mathrm{P} \leq 0.01)$ at 4 hrs post-feeding as it was low per-feeding.

Dehority and Orpin, (1988) showed that diets containing between 40 to $60 \%$ concentrate supported maximal protozoa numbers with a diverse fauna containing species in most of the genera, as concentrates provide a source of rapidly fermentable carbohydrates for ruminal micro-organisms. The improvement in ruminal ciliate protozoa numbers (table 10) by exogenous enzymes may be due to enhancing the hydrolytic capacity of the rumen due to added enzyme activities and/or synergy with rumen microbial enzymes (Morgavi et al., 2000), or may be due to that enzymes were able to degrade complex substrate to simpler ones, allowing a faster ruminal microbial colonization and fermentation (Colombatto et al., 2003).

Table (10): Identification and density of ruminal ciliate protozoa species for Barki sheep fed on the experimental diets.

\begin{tabular}{|c|c|c|c|c|c|c|c|c|}
\hline \multirow[b]{2}{*}{ Item } & \multirow[b]{2}{*}{ Time } & \multicolumn{6}{|c|}{ Treatment } & \multirow[t]{2}{*}{ Overall mean } \\
\hline & & D1 & D2 & D3 & D4 & D5 & $\pm \mathrm{SE}$ & \\
\hline Total protozoa & 0 & 6.724 & 6.282 & 6.900 & 7.058 & 7.206 & 0.420 & $6.834^{\mathrm{b}} \pm 0.188$ \\
\hline $\begin{array}{l}\text { count } \times 10^{4} \text { cell } \\
/ \mathrm{ml} \text { rumen liquor }\end{array}$ & 4 & 6.820 & 6.551 & 7.123 & 7.237 & 7.388 & 0.420 & $7.024^{\mathrm{a}} \pm 0.188$ \\
\hline Overall mean & & $6.772^{c}$ & $6.416^{\mathrm{d}}$ & $7.012^{\mathrm{b}}$ & $7.148^{\mathrm{ab}}$ & $7.297^{\mathrm{a}}$ & 0.297 & \\
\hline Entodinum spp. & 0 & 5.266 & 4.917 & 5.378 & 5.458 & 5.505 & 0.341 & $5.305^{\mathrm{b}} \pm 0.152$ \\
\hline & 4 & 5.390 & 5.200 & 5.625 & 5.677 & 5.730 & 0.341 & $5.524^{\mathrm{a}} \pm 0.152$ \\
\hline Overall mean & & $5.328^{\mathrm{c}}$ & $5.058^{\mathrm{d}}$ & $5.501^{\mathrm{b}}$ & $5.567^{\mathrm{ab}}$ & $5.617^{\mathrm{a}}$ & 0.241 & \\
\hline Epidinium spp. & 0 & 0.172 & 0.166 & 0.172 & 0.180 & 0.198 & 0.016 & $0.177^{\mathrm{b}} \pm 0.007$ \\
\hline & 4 & 0.182 & 0.174 & 0.185 & 0.185 & 0.198 & 0.016 & $0.185^{\mathrm{a}} \pm 0.007$ \\
\hline Overall mean & & $0.177^{\mathrm{c}}$ & $0.170^{\mathrm{c}}$ & $0.178^{\mathrm{c}}$ & $0.183^{\mathrm{b}}$ & $0.198^{\mathrm{a}}$ & 0.011 & \\
\hline Diplodinum spp. & 0 & 0.130 & 0.124 & 0.139 & 0.157 & 0.172 & 0.013 & $0.144^{\mathrm{b}} \pm 0.006$ \\
\hline & 4 & 0.150 & 0.141 & 0.155 & 0.167 & 0.180 & 0.013 & $0.158^{\mathrm{a}} \pm 0.006$ \\
\hline Overall mean & & $0.140^{\mathrm{b}}$ & $0.132^{\mathrm{c}}$ & $0.147^{\mathrm{b}}$ & $0.162^{\mathrm{ab}}$ & $0.176^{\mathrm{a}}$ & 0.009 & \\
\hline Ophryoscolox spp & 0 & 0.172 & 0.147 & 0.184 & 0.188 & 0.196 & 0.009 & $0.177^{\mathrm{b}} \pm 0.004$ \\
\hline & 4 & 0.174 & 0.154 & 0.189 & 0.208 & 0.223 & 0.009 & $0.190^{\mathrm{a}} \pm 0.004$ \\
\hline Overall mean & & $0.173^{\mathrm{c}}$ & $0.151^{\mathrm{d}}$ & $0.186^{\mathrm{b}}$ & $0.198^{\mathrm{ab}}$ & $0.210^{\mathrm{a}}$ & 0.006 & \\
\hline Polyolastron spp. & 0 & 0.336 & 0.307 & 0.348 & 0.358 & 0.376 & 0.023 & $0.346^{\mathrm{b}} \pm 0.010$ \\
\hline & 4 & 0.337 & 0.318 & 0.353 & 0.373 & 0.411 & 0.023 & $0.357^{\mathrm{a}} \pm 0.010$ \\
\hline Overall mean & & $0.336^{\mathrm{c}}$ & $0.312^{\mathrm{d}}$ & $0.350^{\mathrm{b}}$ & $0.365^{\mathrm{ab}}$ & $0.393^{\mathrm{a}}$ & 0.016 & \\
\hline Isotrchia spp. & 0 & 0.206 & 0.197 & 0.215 & 0.229 & 0.243 & 0.014 & $0.218^{\mathrm{b}} \pm 0.006$ \\
\hline & 4 & 0.207 & 0.210 & 0.225 & 0.233 & 0.249 & 0.014 & $0.222^{\mathrm{a}} \pm 0.006$ \\
\hline Overall mean & & $0.207^{\mathrm{b}}$ & $0.203^{\mathrm{b}}$ & $0.220^{\mathrm{ab}}$ & $0.231^{\mathrm{ab}}$ & $0.246^{\mathrm{a}}$ & 0.010 & \\
\hline Dasytrachia spp. & 0 & 0.409 & 0.373 & 0.419 & 0.422 & 0.439 & 0.019 & $0.412^{\mathrm{b}} \pm 0.008$ \\
\hline & 4 & 0.410 & 0.401 & 0.434 & 0.456 & 0.471 & 0.019 & $0.434^{\mathrm{a}} \pm 0.008$ \\
\hline Overall mean & & $0.410^{\mathrm{bc}}$ & $0.387^{\mathrm{c}}$ & $0.426^{\mathrm{b}}$ & $0.439^{\mathrm{ab}}$ & $0.455^{\mathrm{a}}$ & 0.013 & \\
\hline
\end{tabular}

Means with different letters with each row are significantly different $(P \leq 0.01)$.

TPC $(P=0.297)$, Entodinum $(P=0.495)$, Epidinium $(P=0.548)$, Diplodinum $(P=0.035)$, Ophryoscolox $(P=$ $0.246)$, Polyolastron $(P=0.038)$, Isotrchia $(P=0.063)$, Dasytrachia $(P=0.027)$.

The present results are supported by the results of Ivan et al. (2000) who reported that Entodinium was the most detrimental of ciliate protozoa species. Morgavi et al., (2000) and Nsereko et al., (2000) found that direct-fed enzymes can enhance microbial colonization of feed by increasing numbers of ruminal fibrolytic microbes. Nsereko et al. (2002) reported that exogenous enzymes may affect certain groups of ruminal micro-organisms. Also, Shakweer (2003) indicated that addition of bacteria (Cellulomonas cellulans) to sugarcane bagasse and rice straw fermented with yeast (Saccharomyces cerevisiae) plus fungi (Phanerochaete chrsysosporium) in the diet of mature rams increased protozoa counts at $3 \mathrm{~h}$ post-feeding compared to those treated with yeast plus fungi only. Moreover, Kholif and Aziz (2014) indicated a significant $(\mathrm{P}<0.01)$ increase of ruminal ciliate protozoa counts by the addition of cellulytic enzymes in goats diet contained date by- products, also all species were significantly $(\mathrm{P}<0.01)$ affected by time of feeding. Moreover, the data indicated that Entodinum sp recorded the largest count of 
total among all different species of ruminal protozoa for all treatments. The same results of ruminal ciliate protozoa for sheep and goats with croup residues were obtained by Aziz (2014 and 2015).

\section{Blood serum measurements:}

Serum total proteins and albumin concentrations $(\mathrm{g} / \mathrm{dl})$ were significant $(\mathrm{P} \leq 0.01)$ increased with diets contained DPL incubated with enzymes more than that of control and non-enzymatic diets (Table 10). Diet incubated with combination of enzymes (D5) had the highest $(\mathrm{P} \leq 0.01)$ values followed by diet of Fibrolytic enzyme (D4) then diet of Cellulase enzyme (D3), while, diet received no enzymes showed the lowest $(\mathrm{P} \leq 0.01)$ concentrations. Globulin $(\mathrm{g} / \mathrm{dl})$, albumin/ globulin and GPT (U/L) concentrations were not affected by the diets. Serum urea $(\mathrm{mg} / \mathrm{dl})$ and GOT $(\mathrm{U} / \mathrm{L})$ concentrations were significant $(\mathrm{P} \leq 0.01)$ decreased with enzymatic diets compared to non- enzymatic and control diets, where D5 had the lowest concentrations. The present results indicate that including DPL not or incubated with enzymes in diets did not any effect on liver and kidney functions of sheep. All serum components concentrations were affected by sampling time as they increased $(\mathrm{P} \leq 0.01)$ at $4 \mathrm{~h}$ post-feeding compared to pre-feeding concentrations.

Similar results were obtained with biological treatments by Kholif et al. (2001), and Aziz (2009, 2014, and 2015) who reported that biological treatments increased total proteins albumin and globulin concentrations, and decreased urea concentration, GOT and GPT activity in blood serum. Also Mohamed and Abou-Zeina (2008) reported similar results with biologically treated sugar beet pulp.

Table (11): Blood serum measurements for Barki sheep fed on the experimental diets.

\begin{tabular}{|c|c|c|c|c|c|c|c|c|}
\hline \multirow[t]{2}{*}{ Item } & \multirow[b]{2}{*}{ Time } & \multicolumn{6}{|c|}{ Treatment } & \multirow[t]{2}{*}{ Overall mean } \\
\hline & & D1 & D2 & D3 & D4 & D5 & $\pm \mathrm{SE}$ & \\
\hline \multirow[t]{2}{*}{ Total proteins g/dl } & 0 & 8.31 & 8.17 & 8.91 & 9.14 & 9.50 & 0.250 & $8.80^{b} \pm 0.112$ \\
\hline & 4 & 8.78 & 8.45 & 9.27 & 9.58 & 10.15 & 0.250 & $9.24^{\mathrm{a}} \pm 0.112$ \\
\hline Overall mean & & $8.55^{\mathrm{d}}$ & $8.31^{\mathrm{e}}$ & $9.09^{c}$ & $9.36^{\mathrm{b}}$ & $9.82^{\mathrm{a}}$ & 0.177 & \\
\hline \multirow[t]{2}{*}{ Albumin g/dl } & 0 & 4.75 & 4.53 & 5.06 & 5.40 & 6.14 & 0.282 & $5.18 \pm 0.126$ \\
\hline & 4 & 4.91 & 4.63 & 5.27 & 5.47 & 6.10 & 0.282 & $5.27 \pm 0.126$ \\
\hline Overall mean & & $4.83^{\mathrm{d}}$ & $4.58^{\mathrm{e}}$ & $5.16^{\mathrm{c}}$ & $5.44^{\mathrm{b}}$ & $6.12^{\mathrm{a}}$ & 0.199 & \\
\hline \multirow[t]{2}{*}{ Globulin g/dl } & 0 & 3.56 & 3.63 & 3.84 & 3.73 & 3.36 & 0.337 & $3.62 \pm 0.150$ \\
\hline & 4 & 3.86 & 3.81 & 4.00 & 4.10 & 4.05 & 0.337 & $3.96 \pm 0.150$ \\
\hline Overall mean & & 3.71 & 3.72 & 3.92 & 3.92 & 3.70 & 0.238 & \\
\hline \multirow[t]{2}{*}{$\mathrm{A} / \mathrm{G}$ ratio } & 0 & 1.33 & 1.26 & 1.60 & 1.52 & 1.85 & 0.237 & $1.51 \pm 0.106$ \\
\hline & 4 & 1.37 & 1.25 & 1.32 & 1.34 & 1.51 & 0.237 & $1.36 \pm 0.106$ \\
\hline Overall mean & & 1.35 & 1.25 & 1.46 & 1.43 & 1.68 & 0.167 & \\
\hline \multirow[t]{2}{*}{ Urea mg/dl } & 0 & 32.92 & 29.74 & 26.22 & 25.50 & 24.48 & 22.91 & $27.77^{\mathrm{b}} \pm 1.095$ \\
\hline & 4 & 30.40 & 37.75 & 29.04 & 28.08 & 27.16 & 24.10 & $30.48^{\mathrm{a}} \pm 1.095$ \\
\hline Overall mean & & $31.66^{\mathrm{b}}$ & $33.74^{\mathrm{a}}$ & $27.63^{c}$ & $26.79^{\mathrm{cd}}$ & $25.82^{d}$ & 1.732 & \\
\hline \multirow[t]{2}{*}{ GOT U/L } & 0 & 24.11 & 22.62 & 22.31 & 21.58 & 4.50 & 5.47 & $22.70 \pm 0.544$ \\
\hline & 4 & 25.68 & 24.04 & 23.42 & 22.14 & 5.75 & 5.81 & $23.87 \pm 0.544$ \\
\hline Overall mean & & $23.51^{\mathrm{ab}}$ & $24.89^{\mathrm{a}}$ & $23.33^{b c}$ & $22.86^{\mathrm{bc}}$ & $21.86^{\mathrm{c}}$ & 0.861 & \\
\hline \multirow[t]{2}{*}{ GPT U/L } & 0 & 4.50 & 5.47 & 4.27 & 4.60 & 4.50 & 0.595 & $4.67 \pm 0.266$ \\
\hline & 4 & 5.75 & 5.81 & 5.45 & 5.25 & 4.77 & 0.595 & $5.40 \pm 0.266$ \\
\hline Overall mean & & 5.12 & 5.64 & 4.86 & 4.92 & 4.63 & 0.421 & \\
\hline
\end{tabular}

Means with different letters with each row are significantly different $(P \leq 0.01)$.

$T P(P=0.427)$, Albumin $(P=0.773)$, Globulin $(P=0.494), A / G$ ratio $(P=0.568)$, Urea $(P=0.803), G O T(P=$ 0.419), $G P T(P=0.786)$.

\section{CONCLUSION}

Feeding diets contained $40 \%$ date palm leaves had no inverse effect on sheep performance compared to control (based on berseem hay only). The addition of Cellulase and Fibrolytic enzymes and combinations with each other to diets contained $40 \%$ date palm leaves improved nutrients digestibility and enhanced nitrogen balance, therefor, rumen fermentations, microbial protein, ruminal ciliate protozoa counts and blood composition were improved comparing to diets without enzymes.

\section{REFERENCES}

Abdou, Ahlam R. (2017). Utilization of allzyme SSF to improve the nutritive value of olive cake in sheep. Egyptian J. Nutrition and feeds. 20 (30):379-387. 


\section{Egyptian J. Nutrition and Feeds (2020)}

Adesogan, A.T. (2005). Improving forage quality and animal performance with fibrolytic enzymes. In:2005 Florida Ruminants Nutrition Symposium, pp. 91-109.

Allam, M. Sabbah; T.M. Al-Bedawi; Hanaa H. El-Amary and Shereen H. Mohamed (2006). Improving sugar beer pulp through biological treatment and its use in sheep ration. Egyptian J. Nutrition and Feeds.9(2): 235-247.

AOAC (1995). Association of Official Analytical Chemists. Official methods of analysis. $15^{\text {th }}$ ed. Arlongton, Virginia, USA.

ARC (1984). The nutrient requirement of Ruminant Livestock, Supplement 1. Commonwealth Agriculture Bureaux, Slough, UK.

Armstrong, W.D. and C.W. Carr, (1964). Physiological Chemistry, 3ed Edn. Laboratory Directions Bures Publishing Co. Minneapolis, Minnesota, USA.

Awawdeh, M.S. and B.S. Obeidat (2013). Treated olive cake as non-forage fiber source for growing Awassi lambs: Effects on nutrient intake, rumen and urine $\mathrm{pH}$, performance, and carcass yield. Asian Australas. J.Anim. Sci. may, 26(5)661-667.

Aziz ,Hend. A. (2004). Studies on effect of some non- hormonal growth promoters on growth rate and some rumen parameters in small ruminants under desert condition. M. Sc. Thesis, Fac. of Agric., Ain Shams Univ.

Aziz, Hend. A. (2009). Effect of feeding olive tree pruning by-products in Sinai on sheep performance. Ph. D. thesis, Fac. of Agric., Ain Shams Univ.

Aziz, Hend. A. (2014). Effect of biologically treated sugar beet pulp on chemical composition, nutrients disappearance, digestibility, rumen fermentations, rumen microbes and blood composition in adult sheep. J. Agric Sci. Mansoura Univ., 5(12): 647-671.

Aziz, Hend. A. (2015). Effect of biologically treated sugar beet pulp on lactating goat performance. J. Agric Sci. Mansoura Univ., 6 (6): 301-327.

Bedford (2002). The role of carbohydrates in feedstuff digestion. Pages 319-336 in Poultry Feedstuffs:Supply, Composition and Nutritive Value. J. MacNab and N. Booraman, ed. CAB International, Wallingford, UK.

Beever D.E. and R.C. Siddons (1986). Digestion and metabolism in the grazing ruminant. In Control of Digestion and Metabolism in Ruminants, pp. 479-497 In: L. P. Milligan, W. L. Grovum, A. Dobson, (editors). New Jersey: Prentice-Hall.

Chen, X.B.; S.A. Abdulrazak; W.J. Shand and E.R. Ørskov (1992). The effect of supplementing straw with barleyor unmolassed sugar beet pulp on microbial protein in sheep estimated from urinary purine derivatives excretion. Animal Production, 55:413-417.

Chen, X.B. and M.J. Gomaes (1995). Estimation of microbial protein supply to sheep and cattle based on urinary excretion of purine derivatives. In: An Overerview of the Technical Details. Occasional Publication 1992. International Feed Resources Unit, Rowett Research Institute, Aberdeen, UK.

Church, D.C. and W.G.Pond (1982). Basic animal nutrition and feeding, 2nd ed. Johnwiley and sons, New York, U.S.A.

Clark, J.H.; T.H. Klusmeyer and M.R. Cameron (1992). Microbial protein Synthesis and owes of nitrogen fractions to duodenum of dairy cows. J dairy Sci., 75:2304-2323.

Coleman G.S. (1980). Advances in Parasitology 18, 121-173.

Colombatto, D; F.L. Mould; M.K. Bhat; D.P. Morgavi and K.A. Beauchemin and E. Owen (2003). Influence of fibrolytic enzymes on the hydrolysis and fermentation of pure cellulose and xylan by mixed ruminal microganisms in vitro. J. Anim. Sci., 81:1040-1050.

Crampton, E.W.; L.E. Lioyd and V.G. Mackay (1957). The calorie value of TDN. J. Ani. Sci., 16:541545.

DeFrain, J.M.; A.R. Hippen; K.F. Kalscheur and J.M. Tricarico (2005). Feeding alpha-amylase improves the glycemic status and performance of transition dairy cows. Journal of Dairy Science, 88: 44054413. 
Dehority, B. A. (1993). Laboratory Manual for classification and Morphology of rumen ciliate protozoa. CRC. Press Inc., Florida.

Dehority, B. A. and C. G. Orpin (1988). Development of, and natural fluctuations in, rumen microbial populations. In: P.N. Hoboson (Ed.) The Rumen Microbia Ecosystem. PP. 151- 183. Elsevier Applied Science, London.

Doumas,W. and H. Biggs (1971). Albumin standards and measurement of serum with bromocresOl green. Din. Chern. Acta. 31: 87.

Duncan, D.B. (1955). Multiple range and multiple F-test. Biometrics. 11:1-42.

El-Ashry, M.A.; M.F. Ahmed; S.A. El-Saadany; M.E.S. Youssef ; I.A. Gommaa and T.A.A. Deraz (1997). Effect of mechanical vs. mechano-chemical or mechano-biochemical treatments of crop residues on their use in ruminant rations: Digestibility, nitrogen balance and some blood and rumen liquor parameters of sheep. Egyptian J. Nutrition and Feeds, 1: (Special Issue): 173-186.

FAO (2006). Food and Agriculture Organization of the United Nations, Rome, Italy: Date palm cultivation.

Fouad, R.T. (1991). Effect of some mechanical treatments and feed additives on the nutritional value of corn stalks. M.Sc. Thesis, Fac. of Agric., Al-Azhar Univ.

Fujihara, T.; E.R. Ørskov and P.J. Reeds (1987). The effect of protein infusion on urinary execration of purine derivatives in ruminants nourished by intragastric nutrition. J. Agric. Sci., 109:7-12.

Gado, H.M. and R.I. Abd El-Galil (2009). Evaluation differences of some ruminal bacteria by in vitro dry matter, cellulose and hemicellulose disappearance rate and extent of bagasse. Egyptian J. Nutrition and Feeds. 12 (3):359-372.

Gado, H.M.; H.M. Metwally; H. Soliman; A.Z.L. Basiony and E.R. El Galil (2007). Enzymatic treatments of bagass by different sources of cellulase enzymes. In: Proceedings of 11th Conference on Animal Nutrition, Al-Aqsor-Aswan, Egypt, November 13-18, 2007, vol. 10: 607.

Gado, H.M.; A.Z.M.Salem; P.H. Robinson; and M. Hassan (2009). Influence of exogenous enzymes on nutrient digestibility, extent of ruminal fermentation as well as milk production and composition in dairy cows. Animal Feed Science and Technology, 154: 36-46.

Goli, S. and H. Aghdam Shahryar (2015). Effect of enzymes supplementation (Rovabio and Kemin) on some blood biochemical parameters, performance and carcass characterizes in broiler chickens. Iranian J. of Applied Anim. Sci., 5(1): 127-131.

Gomaa, A.A.A.I., M.Y. Mohamed, Fattma E. Saba, E.M.M. Ibrahim A.A. El-Giziry (2016). Growth performance of Ossimi lambs as affective microorganisms.

Hanafy, M.A.; S.H. Mervat Youssef; M. Azza Badr; M.A. Wafaa Ghoneem and M.R. Rashid (2015). In Vitro evaluation of diets containing crude glycerol as a substitute for corn with some additives. Egyptian J. nutrition and feeds 18 (2): 203-211.

Hoover, W.H. (1986). Chemical factors involved in ruminal fiber digestion. J. Dairy Sci., 69:2755-2766.

Ibrahim, M.R., H.M. El-Banna and M.A. El-Manylawi (2010). Evaluating utilization of ground date stone meal with or without kemzyme in the diets of growing New Zealand rabbits. IV International Date Palm Conference, 15-17 March, 2010, Abo Dubi, UAE, Acta Hort. (ISHS) 882:691-697.

Ivan, M.; L. Neill; R. Forster; R. Alimon; T.L.M. Rode and T. Entz (2000). Effects of Isotricha, Dasytricha, Entodinium, and total Fauna on Ruminal fermentation and duodenal flow in wethers fed different diets. J. Dairy Sci. 83: 776-787.

Khattab, I.M; A.M. Abdel-wahed and K.Z. Kewan (2013). Effect of replacing corn grains with Azzawi dates in sheep diets on intake, digestibility, purine derivatives excretion, microbial nitrogen and rumen fermentation. Egyptian J. nutrition and feeds 16 (1): 239-248.

Khattab, M.S.; S.A.H. Abo El-Nor; H.M.A. El-Sayed; N.E. El-Bordeny; M.M. Abdou and O.H. Matloup (2012). The effect of replacing corn with glycerol and fibrolytic enzymes on the productive performance of lactating goats. International J. Dairy Sci., 7:95-102. 


\section{Egyptian J. Nutrition and Feeds (2020)}

Kholif, A. M.; H. A. El-Alamy; M. A. El-Ashry; H. M. El-Sayed, M. Fadel and S. M. Kolif (2001). Biological treatments of Banana wastes for locating Goats Feeding. Egypteian J. Nutrition and feeds 4 special issue: $437-438$.

Kholif, A.M.; M.A. El-Ashry; H.A. El-Alamy; H.M. El-Sayed; M. Fadel; and S.M. Kholif (2005). Biological treatments of banana wastes for feeding lactating goats. Egyptian J. Nutrition and feeds. (2): 149-162.

Kholif, A.M. and Hend. A. Aziz (2014). Influence of feeding cellulytic enzymes on performance, digestibility and ruminal fermentation in goats. Animal Nutrition and Feed Technology, 14: 121-136.

Krueger, N.A. and A.T. Adesogan (2008). Effect of different mixtures of fibrolytic enzymes on the digestion and fermentation of Bahiagrass hay. Animal Feed Science and Technology, 145: 84-94.

Kung, L.Jr.; R.J. Treacher; G.A. Nauman; A.M. Smagala; K.M. Endres and M.A. Cohen (2000). The effect of treing forages with fibrolytic enzymes on nutritive value and lactation performance of dairy cows. J. Dairy Sci., 83:115-122.

Lazaro, R.; M. Garcia; M.J. Aranibar and G.G. Mateos (2003). Effect of enzyme addition to wheat, barley and rye-based diets on nutrient digestibility and performance of laying hens. British Poultry Science, 44:256-265.

Makkar, H.P.S.; O.P. Sharma; R.K. Dawra; S.S. Negi (1982). Simple Determination of Microbial Protein in Rumen Liquor. J. Dairy Sci., 65:2170-2173.

McAllister, T.A; A.N. Hristov; K.A. Beauchemin; L.M. Rode and K.J. Cheng (2001). Enzymes in ruminant diets. In: Enzymes in Farm Animal Nutrition (Eds. M. Bedford and G. Partridge), CABI Publishing, Oxon, UK, pp. 273-298.

Mohamed, M. I. and Hala A. A. Abou-Zeina (2008). Effect of dietary supplementation with biologically treated Sugar beet pulp on performance and organs fuction in goat kids. American-Eurasian. J. Agric. \& Environ. Sci., 4(4):410-416.

Morgavi, D.P.; K.A. Beauchemin; V. Nsereko; L.M. Rode; A.D. Iwaasa; W.Z. Yang; T.A. McAllister and Y. Wang (2000). Synergy between ruminal fibrolytic enzymes and enzymes from Trichoderma longibrachiatum. Journal of Dairy Science, 83: 1310-1321.

Norris, K.H. (1976). Predicting forage quality by infrared reflectance spectroscopy. J.Anim. Sci., 43:889.

Nsereko, V.L.; K.A. Beauchemin; D.P. Morgavi; L.M. Rode; A.F. Furtado; T.A. McAllister; A.D. Iwaasa; W.Z. Yang and Y. Wang (2002). Effect of a fibrolytic enzyme preparation from Trichoderma longibrachiatum on the rumen microbial population of dairy cows. Canadian Journal of Microbiology, 48: $14-20$.

Nsereko, V.L., D.P. Morgavi; L.M. Rode; K.A. Beauchemin and T.A. McAllister (2000). Effects of fungal enzyme preparations on hydrolysis and subsequent degradation of alfalfa hay fiber by mixed rumen micro-organisms in vitro. Animal Feed Science and Technology, 88:153-170.

Ogimoto, K. and Imai, S. (1981). Atals of Rumen Microbial-Ogy. Japan Scientific Societies Press, ToKyo.

Okab, B .A; A. M. Ayoub; S. M. Emad; K. A. Abdoun; A. A. Al-Haidary; A.A. Koriem and A.A. Hassan (2012). Improvement of growth and nitrogen utilization in sheep using sugar beet pulp treated with Trichoderma reesei or urea. Trop Anim Health Prod. 10:1-7.

Patton, C. J. and Crouch (1977). spectrophotomentic and kinetics investigation of the Berthelot reaction for the determination of ammonia. Anal. Chem., 49: 464-469.

SAS (2009). SAS User's Guide: Statistics. Version 9.2. SAS Inst. Inc., Cary, NC., USA. pp. 7869.

Shakweer, I.M.E. (2003). Effect of biological treatments of rice straw and sugarcane bagass on their digestibility, nutritive value, ruminal activity and some blood parameters in rams. Egyptian Journal of Nutrition and Feeds, 6: 925-940.

Shoukry, M.M. (1992). Effect of urea treatment on chemical composition, In vitro dry matter disappearance and degradability of dry matter and cell wall constituents of some poor quality roughages. Annals of Agric. Moshtohor, 30:677. 
Soliman, M.S. (2006). Utilization of Peanut Hay in Ruminant Feeding. PhD Thesis. Alexandria University, Alexandria, Egypt.

Stella, A.V.; R. Paratte; L. Valnegri; G. Cigalino; G. Soncini; E. Chevaux; V. Dell'Orto and G. Savoini (2007). Effect of administration of live Saccharomyces cerevisiae on milk production, milk composition, blood metabolites, and faecal flora in early lactating dairy goats. Small Ruminant Research, 67: 7-13.

Van Soest, P. J. (1994). The Nutritional Ecology of the Ruminant, $2^{\text {nd }}$ edition. Cornell University press. Ithaca, N Y., 476p.

Warner, A.C.J. (1964). Production of volatile fatty acids in the rumen methods of measurments. Nutr. Abst. \& rev.34:339.

Wikison, J.H., D.N. Barn, D.W. Moss and P.G. Walker (1972). Standardization of clinical enzyme assays. A reference method for aspartate and alanine transaminases. J. Clin. Pathol., 25:940.

Williams, A.G. and G.S. Coleman (1997). The rumen anaerobic fungi. In: The Rumen Microbial Ecosystem (Eds. P.N. Hobson and C.S. Stewart), Kluwer Academic and Publishers, Book News, Inc., Portland, pp. 73-139.

Yang, W.Z.; K.A. Beauchemin and L.M. Rode (1999). Effects of an enzyme feed additive on extent of digestion and milk production of lactating dairy cows. Journal of Dairy Science, 82: 391-403.

Young, E.G. and C.F. Conway (1942). On the estimation of Allantion by the Rimini-Schryver reaction. Journal of Biological Chemistry, 142: 839.

الاستفادة من سعف النخيل المعامل بالانزيمات فى تغذية المجترات الصغيرة

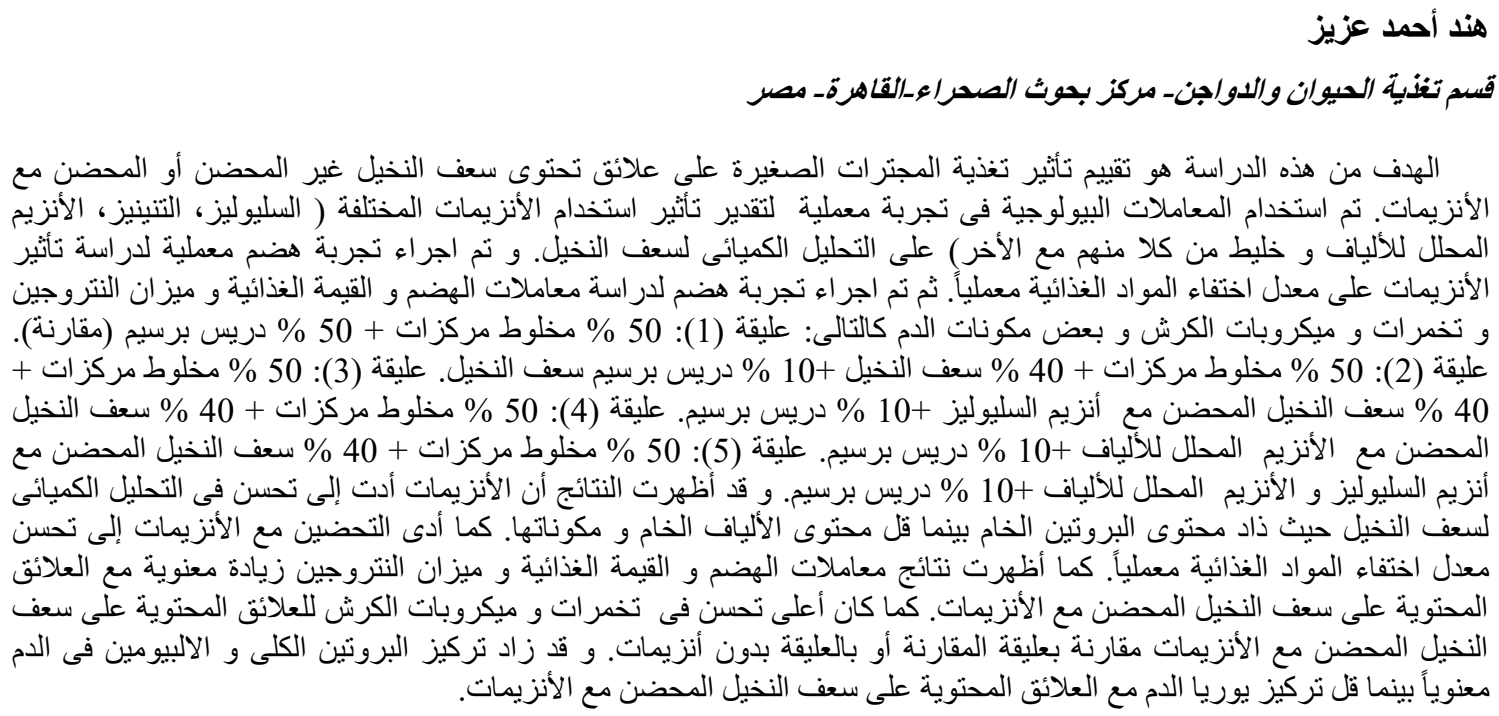

